\title{
Purinergic Signaling in the Vertebrate Olfactory System
}

\author{
Natalie Rotermund, Kristina Schulz, Daniela Hirnet and Christian Lohr* \\ Division of Neurophysiology, University of Hamburg, Hamburg, Germany
}

Adenosine $5^{\prime}$-triphosphate (ATP) is an ubiquitous co-transmitter in the vertebrate brain. ATP itself, as well as its breakdown products ADP and adenosine are involved in synaptic transmission and plasticity, neuron-glia communication and neural development. Although purinoceptors have been demonstrated in the vertebrate olfactory system by means of histological techniques for many years, detailed insights into physiological properties and functional significance of purinergic signaling in olfaction have been published only recently. We review the current literature on purinergic neuromodulation, neuron-glia interactions and neurogenesis in the vertebrate olfactory system.

Keywords: purinergic signaling, olfactory system, olfaction, ATP, adenosine receptor, P2X receptor, P2Y receptor

\section{INTRODUCTION}

Since the discovery of adenosine $5^{\prime}$-triphosphate (ATP) release from sensory nerve terminals (Holton, 1959) and peripheral purinergic neurotransmission (Burnstock et al., 1970), ATP has been described as a (co-)transmitter in most if not all parts of the vertebrate nervous system. ATP is stored in and released from synaptic vesicles but alternative release pathways such as diffusion through connexin and pannexin hemichannels, volume-regulated anion channels and $\mathrm{P}_{2} \mathrm{X}_{7}$ receptor channels have been published (Bodin and Burnstock, 2001; Taruno, 2018). Once released into the extracellular space, ATP activates a specific subclass of purinoceptors, the $\mathrm{P} 2$ receptors. $\mathrm{P} 2$ receptors can further be subdivided into ionotropic P2X receptors and metabotropic P2Y receptors (Burnstock et al., 2011). P2X receptors comprise seven subtypes, named $\mathrm{P}_{2} \mathrm{X}_{1}$ to $\mathrm{P} 2 \mathrm{X}_{7}$, that form non-selective cation channels with high calcium permeability (North, 2016; Schmid and Evans, 2019). In the extracellular space, ATP immediately undergoes enzymatic degradation. Remarkably, a variety of purinoceptors is additionally, if not exclusively, sensitive for the degradation products. The first step of enzymatic ATP degradation yields adenosine $5^{\prime}$-diphosphate (ADP), which is able to activate P2Y receptors in addition to ATP. Some P2Y receptors are also activated by the pyrimidines uridine $5^{\prime}$-triphosphate (UTP) and uridine 5'-diphosphate (UDP; Abbracchio et al., 2006). At least nine different P2Y receptors are expressed in vertebrates, however, $\mathrm{P}_{2} \mathrm{Y}_{3}$ appears to be an avian-specific receptor (Webb et al., 1996). P2 $\mathrm{Y}_{1,2,4,6,11,12,13,14}$ are found in mammals and many of them are expressed by brain cells. The primary intracellular targets of $\mathrm{P} 2 \mathrm{Y}$ receptors are heterotrimeric $\mathrm{G}$ proteins, in particular, those containing $\mathrm{G} \alpha_{\mathrm{q} / 11}\left(\mathrm{P} 2 \mathrm{Y}_{1,2,4,6,11}\right)$ and $\mathrm{G} \alpha_{\mathrm{i}}\left(\mathrm{P} 2 \mathrm{Y}_{12,13,14}\right.$; Abbracchio et al., 2006; Köles et al., 2011). Hence, activation of P2Y receptors results in PLC-mediated calcium signaling and PKC activation as well as inhibition of adenylate cyclase. Besides P2 receptors, the family of purinoceptors comprises P1 receptors (Burnstock et al., 2011). P1 receptors are activated by adenosine, which is usually derived from extracellular degradation of ATP, ADP and AMP by ecto-nucleotidases (CD39/NTPDases, E-NPP, CD73) and alkaline phosphatase (Abbracchio et al., 2009; Zimmermann et al., 2012). P1 are subdivided into $A_{1}, A_{2 A}, A_{2 B}$ and $A_{3}$ receptors. Mostly, $A_{1}$ and $A_{3}$ are linked to $G_{i}$ proteins, while $A_{2 A}$ and $A_{2 B}$ are linked to $G_{s}$ 
proteins exerting an impact on the cellular cAMP levels. To finally terminate the purinergic signaling cascade, adenosine is removed by adenosine transporters or converted by adenosine deaminase and adenosine kinase to inosine and AMP, respectively (Boison, 2013; Bagatini et al., 2018; Pastor-Anglada and Pérez-Torras, 2018). Thus, in contrast to other neurotransmitter systems, the degradation of the neurotransmitter ATP does not immediately terminate transmission but generates the neuromodulators ADP and adenosine, which possess their own subsets of receptors and evoke additional cellular responses. Hence, purinergic signaling is by far more complex than other neurotransmitter systems and is determined by the combination of purinoceptors, ATP/adenosine-degrading enzymes and nucleotide/nucleoside transporters. Since this combination changes during development and circadian rhythm and differs significantly between different brain regions and even between microenvironments, purinergic signaling has multiple facets and fulfills a plethora of functions. Postsynaptic P2X receptors, e.g., mediate fast synaptic transmission (Edwards et al., 1992; Evans et al., 1992; Pankratov et al., 2007), whereas P2Y and P1 receptors rather act as neuromodulators. Adenosine, for instance, is a well-known modulator of presynaptic neurotransmitter release at central synapses (Snyder, 1985; Sebastião and Ribeiro, 2009, 2015). In addition, P2Y receptors inhibit presynaptic calcium channels, thereby reducing neurotransmitter release (Sperlágh et al., 2007; Guzman and Gerevich, 2016). Both P1 and P2 receptors are not only expressed by neurons, but also by glial cells (Deitmer et al., 1998; Verkhratsky et al., 2009; Boison et al., 2010). Activation of purinoceptors induces calcium signaling in astrocytes, which triggers the release of gliotransmitters and mediates neurovascular coupling (Pelligrino et al., 2011; Lohr et al., 2014; Köles et al., 2016). Purinergic signaling is also involved in sensory systems, both in sensory organs such as the eye and the cochlea as well as in brain regions contributing to sensory information processing (Housley et al., 2009; Lohr et al., 2011, 2014). In this review article, we summarize recent data on the role of purinergic signaling in cell physiology, adult neurogenesis and odor information processing in the vertebrate olfactory system. Purinergic signaling has also been shown to play important roles in the development of the nervous system (Zimmermann, 2011). However, studies in the olfactory system, even when performed in the developing animal, rarely address the functional role of purines in development, for which reason we will not elaborate on this topic.

\section{STRUCTURE OF THE VERTEBRATE OLFACTORY SYSTEM}

\section{Olfactory Epithelium}

The vertebrate main olfactory system can be divided into distinct hierarchical levels, mainly the olfactory epithelium, the olfactory bulb and the olfactory cortex (Figure 1). In addition, the vomeronasal organ is also part of the vertebrate olfactory system (forming the sensory organ of the additional olfactory system) conveying the detection of pheromones, but we will focus here on the main olfactory system. Odor sensation is initiated by odor molecules flooding the nasal cavity and their detection by olfactory sensory neurons embedded in the olfactory epithelium, a specialized epithelial tissue located in the nasal cavity. Four main cell types provide its functionality; sensory neurons, basal cells, sustentacular cells and microvillar (brush) cells. Olfactory sensory neurons are bipolar neurons with apical poles equipped with cilia that reach into the mucosa covering the epithelium. On the cilia, odorant receptors are located which are activated by odor molecules resulting in excitation of olfactory sensory neurons. Specialized odorant-binding proteins facilitate the solubility of odor molecules in the mucus and therefore are actively involved in the availability of odor molecules for the odorant receptors (Heydel et al., 2013; Pelosi et al., 2014). Since the sensory neurons of the olfactory epithelium are in constant contact with respiratory air containing pathogens and hazardous substances, they have a very limited span of life and have to be replaced by newborn neurons generated from basal cells every few weeks (Brann and Firestein, 2014). Basal cells are stem cells located nearby the basal lamina of the olfactory epithelium. Microvillar cells are microvilli-bearing columnar cells that contact the afferent nerve endings of the trigeminal nerve with their basal surface and mediate the transduction of general sensation (Lucero, 2013). In addition to these cells, the undermost layer of the olfactory epithelium, the lamina propria, harbors olfactory glands (Bowman's glands). They deliver the protein-rich secret onto the air-facing side of the epithelium. Supporting cells, as the name suggests, are non-neuronal cells providing metabolic and physical support for the cell types described above. The axons of olfactory sensory neurons project into the central nervous system forming the first cranial nerve. Many small nerve fascicles pass the perforated cribriform plate to enter the cranial cavity and eventually spread over the surface of their destination area, the olfactory bulb.

\section{Olfactory Bulb}

The vertebrate olfactory bulb, the first relay station of the olfactory sensory pathway, is a highly structured area of the forebrain with a complex cellular architecture. Morphologically and functionally distinct layers harbor diverse specialized populations of neurons and glial cells (Figure 1). The most superficial layer of the olfactory bulb is the olfactory nerve layer. It is composed of sensory axons, which are assembled into fascicles and surrounded by a unique type of glial cells, the olfactory ensheathing cells. Eventually, the axons of the olfactory sensory neurons exit the nerve layer towards deeper layers to terminate in the glomerular layer. Here, they synapse onto apical dendrites of mitral and tufted cells in so-called glomeruli, separated globular neuropil compartments that form distinct processing units for the incoming odor signals. Mitral and tufted cells, the projection neurons of the olfactory bulb, are often regarded as functionally homogenous and therefore collectively named mitral/tufted cells. In addition to sensory axons and mitral/tufted cell dendrites, glomeruli comprise the processes of local interneurons and astrocytes, whose somata are surrounding the glomerular neuropil in which they project 


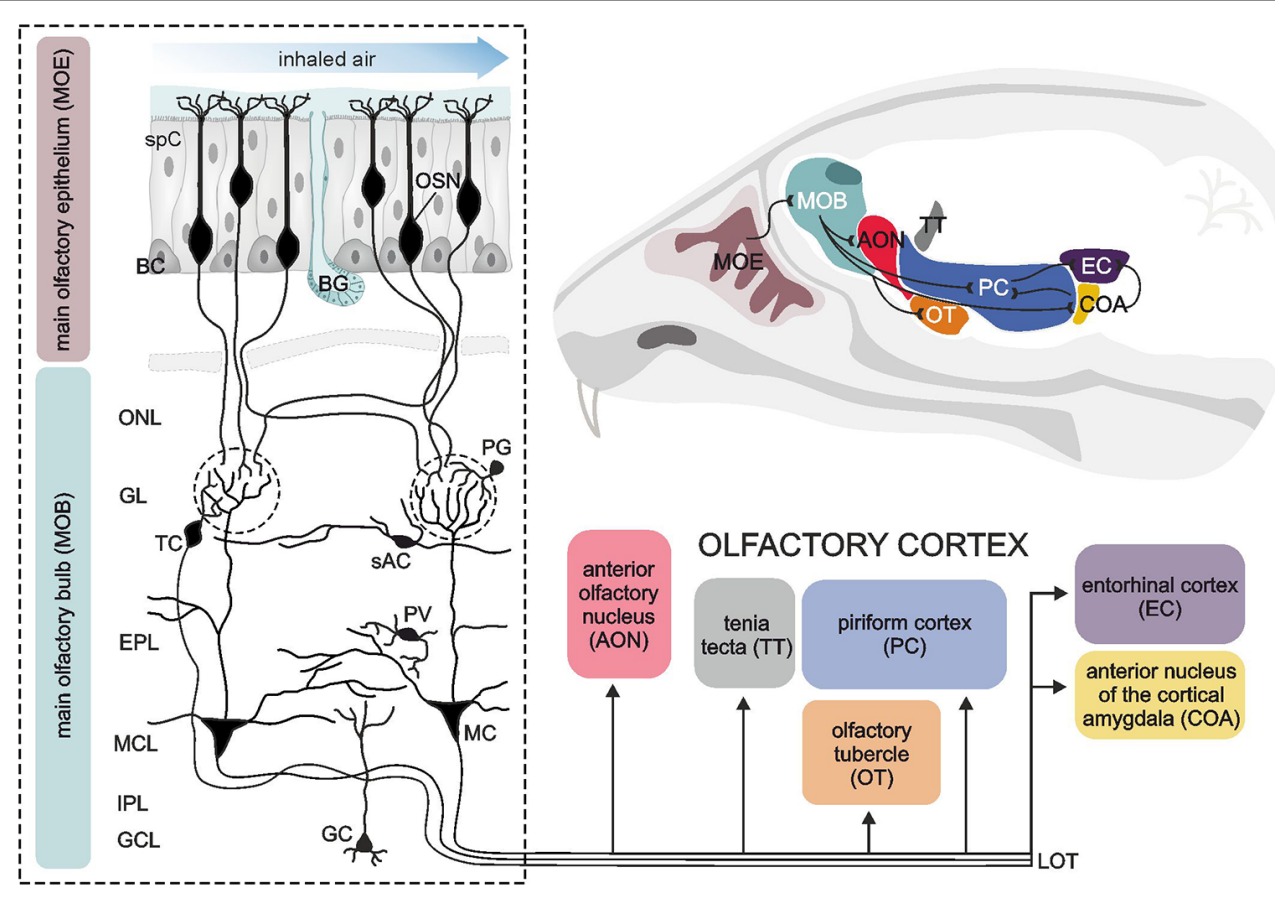

FIGURE 1 | Sensory pathways in the vertebrate olfactory system. A sagittal section of the murine brain (upper right corner) illustrates the components of the vertebrate olfactory system and the connections amongst them (black lines). The dashed box on the left shows a detailed view of the neuronal architecture of the main olfactory epithelium (MOE) and the main olfactory bulb (MOB). The MOE mainly consists of olfactory sensory neurons (OSN), supporting cells (spC) and basal cells $(\mathrm{BC})$ as well as Bowman's glands (BG) providing a mucosa covering the MOE. Volatile odorant molecules are drawn to the nasal cavity by sniffing, pass the mucosa and are detected by OSN. OSN project their axons to the MOB. After passing the olfactory nerve layer (ONL), all OSN expressing the same olfactory receptor converge to the same glomerulus (dashed circles), where the information is synaptically transmitted to second-order neurons, mitral (MC) and tufted cells (TC). The MOB also harbors different types of interneurons, such as periglomerular neurons (PG), short axon cells (SAC), parvalbumin-positive neurons (PV) and granule cells (GC). These interneurons form complex synaptic networks with MC and TC, particularly in the glomerular layer (GL) and the adjacent external plexiform layer (EPL). The somata of MC are located in the mitral cell layer (MCL). The internal plexiform layer (IPL) mainly consists of axons from MC and TC, forming the lateral olfactory tract (LOT). MC and TC generate output via LOT and project their axons to different brain areas referred to as the olfactory cortex, consisting of the anterior olfactory nucleus, tenia tecta, olfactory tubercle, piriform cortex, anterior nucleus of the cortical amygdala and the entorhinal cortex. Illustration by SciGraphics.

(Valverde and Lopez-Mascaraque, 1991; Berkowicz et al., 1994; Ennis et al., 1996; De Saint Jan and Westbrook, 2005; De Saint Jan et al., 2009; Lohr et al., 2014). In the glomeruli, the first level of neuronal processing of odor information is established by feed-forward excitation and feedback inhibition within the axo-dendritic and dendro-dendritic glomerular network. The somata of tufted cells lie in the lower part of the glomerular layer and the adjacent so-called external plexiform layer. Below the external plexiform layer, the cell bodies of mitral cells are located in a single-rowed layer, the mitral cell layer. Mitral cells possess a characteristic morphology with a relatively large, pyramidal cell body and an apical dendrite ending in a single glomerulus. They have few lateral dendrites, branching in the external plexiform layer, where they build reciprocal dendro-dendritic synapses with granule cells and other local interneurons. Thus, the external plexiform layer demarcates a second area of odor signal processing besides the glomerular layer, meaning that mitral/tufted cells integrate two spatially and functionally independent levels of information processing. Just below the mitral cell layer, the axons of mitral/tufted cells assemble and proceed caudally, forming the internal plexiform layer. The deepest layer of the olfactory bulb is mainly filled with granule cells, small axon-less interneurons that project their dendrites to the external plexiform layer.

\section{Primary Olfactory Cortex}

On their way towards the cortical areas, the axons of mitral/tufted cells converge to the lateral olfactory tract, leaving the olfactory bulbs to project to areas of higher ordered sensory processing. The olfactory pathway shows some unique features compared to neuronal pathways of other senses such as vision, hearing and somatosensation. The main part of the information from the olfactory bulb is conveyed straight to cortical areas without passing a thalamic relay first (Gottfried, 2006). These cortical areas, receiving direct input from the olfactory bulb, are designated primary olfactory cortex and extend to the dorsomedial surface of the temporal lobe. As main elements, the primary olfactory cortex comprises (from rostral to caudal) the anterior olfactory nucleus (a.k.a. anterior olfactory cortex), olfactory tubercle, tenia tecta, piriform cortex, anterior cortical nucleus of the amygdala and entorhinal cortex (Figure 1). Apart from the entorhinal cortex, the areas of the primary olfactory cortex 
consist of a three-layered allo-(palaeo-)cortex, pointing to its ancient evolutionary origins (Gottfried, 2006). Notably, all these regions are not exclusively destined to process olfactory information, but, being elements of the limbic system, rather fulfil multiple functions such as processing emotions and memory formation, which can anecdotally be experienced as highly vivid and emotional autobiographical memories triggered by olfactory sensation (Gottfried, 2006; Wilson et al., 2014). The connection between primary olfactory cortex structures and the olfactory bulb is reciprocal, apart from the olfactory tubercle, a structure which is rudimentary in humans and does not feed back to the olfactory bulb (Gottfried, 2006). Most subregions of the primary olfactory cortex are intensely interconnected via cortical fibers with each other and with higher-ordered secondary cortical areas such as the orbitofrontal cortex, mediodorsal thalamus and amygdala (Wilson et al., 2014). A key area of this network producing olfactory perception is the piriform cortex. Despite the relatively simple three-layered cytoarchitecture, the piriform cortex executes diverse operations, which are attributed to higher-ordered associative cortices rather than to primary sensory cortices. For instance, the piriform cortex contributes to decorrelation of odor responses in order to discriminate different odors, pattern completion allowing perceptual stability and encoding the value associated with the odor creating an odor context memory (Haberly, 2001; Courtiol and Wilson, 2017).

\section{SOURCES AND BREAKDOWN OF ATP AND ADENOSINE}

ATP, as intracellular energy supply, is present in all cells and therefore ubiquitously available as an intercellular signaling molecule. Thus, the presence of high amounts of ATP in the extracellular space as a result of injury or cell death seems to be a common signal of cell damage (Burnstock and Verkhratsky, 2009). Apart from that, a controlled release of ATP by exocytosis, active transport or membrane pores is also known for most brain areas (North and Verkhratsky, 2006; Lohr et al., 2011; Burnstock, 2013). Depending on the release pathway, achieved local concentration, the rate of degradation or uptake and the presence of different types of purinoceptors, ATP and other nucleotides transduce or modulate physiological responses in a highly specific manner.

In the olfactory system, the active release of ATP, ADP or adenosine has been described in the olfactory epithelium, the olfactory bulb and the olfactory cortex. ATP is released by exocytosis in the olfactory epithelium and activates both P2Y and P2X receptors (Hegg et al., 2009; Hayoz et al., 2012). In the olfactory bulb, electrical stimulation of axons of olfactory sensory neurons results in co-release of ATP and glutamate at the axon terminals in the glomerular layer as well as alongside the axons in the nerve layer, which was termed "ectopic" release (Thyssen et al., 2010). The concentration of extracellular ATP released from these neurons was estimated to reach the upper micromolar range (Thyssen et al., 2010). The release of ATP from olfactory sensory neurons depends on a rise in intracellular calcium and is suppressed by impairing exocytosis with botulinum toxin, indicating vesicular release (Thyssen et al., 2010). In addition, astrocytes provide a source for extracellular ATP in the olfactory bulb. Roux et al. (2015) demonstrated the significance of astrocytic connexin 43 hemichannels for purinergic neuron-glia communication and baseline ATP levels in the mouse olfactory bulb. ATP-mediated effects on mitral cells are blocked in mice deficient in connexin 43 , a connexin mainly expressed by astrocytes, and by the connexin 43-specific inhibitory peptide Gap26. On the other hand, ATP release from astrocytes via the opening of connexin 43 hemichannels is reduced by tetrodotoxin (TTX) and hence depends on neuronal activity (Roux et al., 2015). The prominent role of astrocytic hemichannels in controlling extracellular ATP is further confirmed by the finding that Gap26 results in a reduction of ambient ATP levels by about $50 \%$ (Roux et al., 2015).

Purinergic signaling is more complex than most other neurotransmitter systems, since extracellular degradation of ATP is not the endpoint of its action, but activates other parts of the purinergic signaling system. A variety of extracellular enzymes, e.g., tissue non-specific alkaline phosphatases and ecto-nucleotidases, catalyze the successive degradation of ATP (Zimmermann, 2006). The activity of these enzymes and of adenosine deaminase is notably high in the olfactory bulb, compared to other brain regions, suggesting a rapid extracellular breakdown from ATP to adenosine and great significance of ATP dephosphorylation products as signaling molecules in the olfactory bulb (Geiger and Nagy, 1987; Schoen and Kreutzberg, 1995, 1997; Clemow and Brunjes, 1996; Langer et al., 2008). Interestingly, the activity of different nucleotide-degrading enzymes differs significantly between different layers of the olfactory bulb. Ecto $5^{\prime}$-nucleotidase (CD73), e.g., has a very high activity in the external and internal plexiform layers as well as in the granule cell layer, while tissue non-specific alkaline phosphatase is active in the glomerular, external and internal plexiform layers (Langer et al., 2008). Physiological experiments in acute olfactory bulb slices provide additional evidence for the importance of tissue non-specific alkaline phosphatase, since its inhibition suppresses the $\mathrm{A}_{2 \mathrm{~A}}$ receptor-dependent calcium response in periglomerular astrocytes upon application of ATP, while inhibition of ecto-nucleotidases with ARL 67156 had no effect (Doengi et al., 2008). A study by Pani et al. (2014) provides data about baseline levels of ATP, ADP, AMP and adenosine in five brain regions, including the olfactory bulb, of five different strains of mice. Using high-performance liquid chromatography with electrochemical detection, they found significant variations of baseline purine levels between brain regions and mouse strains. In the olfactory bulb, total adenosine concentrations varied significantly from about $3,000 \mathrm{pg} / \mathrm{mg}$ wet weight in C57BL/6J mice to about $600,000 \mathrm{pg} / \mathrm{mg}$ wet weight in $\mathrm{BALB} / \mathrm{c}$ mice. In $\mathrm{C} 57 \mathrm{BL} / 6 \mathrm{~J}$ mice, both adenosine and ATP showed the lowest concentrations in the olfactory bulb compared to the other brain regions such as the cerebral cortex and hippocampus (Pani et al., 2014). Yet, whether these variations in total purine concentration also reflect diversity in extracellular purine levels and purinergic 
neuromodulation in different brain areas or mouse strains remains an open question.

\section{PURINERGIC SIGNALING IN THE OLFACTORY EPITHELIUM}

The olfactory epithelium mainly consists of sensory neurons, sustentacular cells, microvillar cells and basal cells (Figure 2). All four cell types have been found to express purinoceptors (Hegg et al., 2003). Immunohistochemical, electrophysiological and calcium imaging studies demonstrated the presence of P2X and P2Y receptors in olfactory sensory neurons (Hegg et al., 2003). Application of ATP excites olfactory sensory neurons and leads to an increase in the cytosolic calcium concentration in explants of the olfactory epithelium of mice and Xenopus tadpoles (Hegg et al., 2003; Czesnik et al., 2006). Despite the excitatory effect of ATP on non-stimulated olfactory sensory neurons, calcium responses upon stimulation by odors are inhibited by co-application of ATP (Hegg et al., 2003). In line with this, odor-evoked responses in olfactory sensory neurons are increased in amplitude when purinoceptors are blocked by the non-specific P2 antagonists PPADS and suramin, indicating purinergic modulation of odor responses by endogenously released ATP (Hegg et al., 2003).

Besides the impact on sensory signal transduction, purinergic agonists such as ATP, ADP and UTP also evoke calcium signaling in sustentacular cells and microvillar cells, linking neuronal activity and trophic functions (Hegg et al., 2003, 2009; Czesnik et al., 2006; Hassenklöver et al., 2008; Jia and Hegg, 2015). In sustentacular cells, ATP and UTP stimulate calcium signaling via $\mathrm{P} 2 \mathrm{Y}$ receptor-mediated calcium release from internal stores (Hassenklöver et al., 2008; Hegg et al., 2009). These calcium signals occur as calcium oscillations in individual cells but can also travel as calcium waves through the gap junction-coupled syncytium of sustentacular cells in the olfactory epithelium (Vogalis et al., 2005a; Hassenklöver et al., 2008; Hegg et al., 2009). Calcium transients in sustentacular cells are accompanied by activation of calcium-dependent BK potassium channels, which results in hyperpolarization of the cell membrane (Vogalis et al., 2005a,b). Degeneration of sensory neurons in the olfactory epithelium evokes the release of ATP (Jia and Hegg, 2010; Hayoz et al., 2012). In neonatal mice, this ATP release is potentiated by ATP-induced ATP release, which involves $\mathrm{P}_{2} \mathrm{X}_{7}$ and $\mathrm{P} 2 \mathrm{Y}$ receptors and results in extracellular ATP concentrations in the low micromolar range (Hayoz et al., 2012). Besides sustentacular cells, the second type of supporting cells, microvillar cells, resides in the olfactory epithelium and expresses purinoceptors (Hegg et al., 2010; Fu et al., 2018). Extracellular ATP evokes calcium signaling in both, sustentacular and microvillar cells, by activation of $\mathrm{P}_{2} \mathrm{Y}_{2}$ and $\mathrm{P}_{2} \mathrm{X}_{7}$ receptors (Figure 2). A subpopulation of microvillar cells that expresses type 3 inositol trisphosphate receptor (IP3R3) and transient receptor potential channel M5 (TRPM5) also expresses the neurotrophic factor neuropeptide Y (NPY); in these cells, P2 receptor-dependent calcium signaling leads to release of NPY (Montani et al., 2006; Kanekar et al., 2009; Jia and Hegg, 2015). Activation of Y1 NPY receptors in basal cells stimulates p44/42 extracellular signal-regulated kinase (ERK), thereby promoting proliferation of basal cells that differentiate into mature olfactory sensory neurons (Jia et al., 2009, 2013; Jia and Hegg, 2012). Upon maturation, these sensory neurons grow
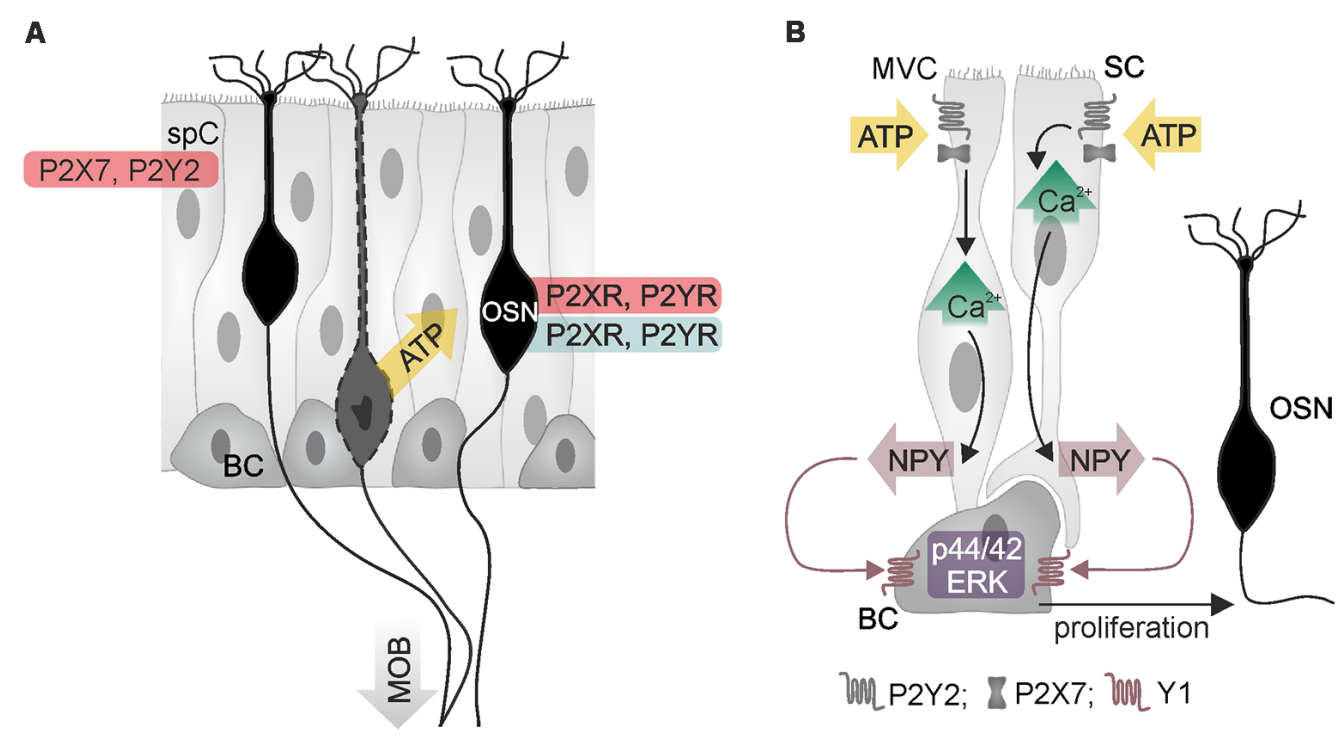

FIGURE 2 | Purinergic signaling in the main olfactory epithelium. (A) Olfactory sensory neurons (OSN) and supporting cells (spC) express P2X and P2Y receptors, as demonstrated by physiological (red) and histological data (blue). Adenosine 5'-triphosphate (ATP) is released from injured or degenerating OSN (yellow arrow). BC, basal cell; MOB, main olfactory bulb. (B) ATP stimulates calcium signaling in two types of supporting cells, microvillar cells (MVC) and sustentacular cells (SC), resulting in the release of neuropeptide $\mathrm{Y}$ (NPY). Activation of Y1 NPY receptors of basal cells stimulates proliferation via p44/42 mitogen-activated protein kinase (extracellular signal-regulated kinase; ERK), which generates new OSN. Illustration by SciGraphics. 


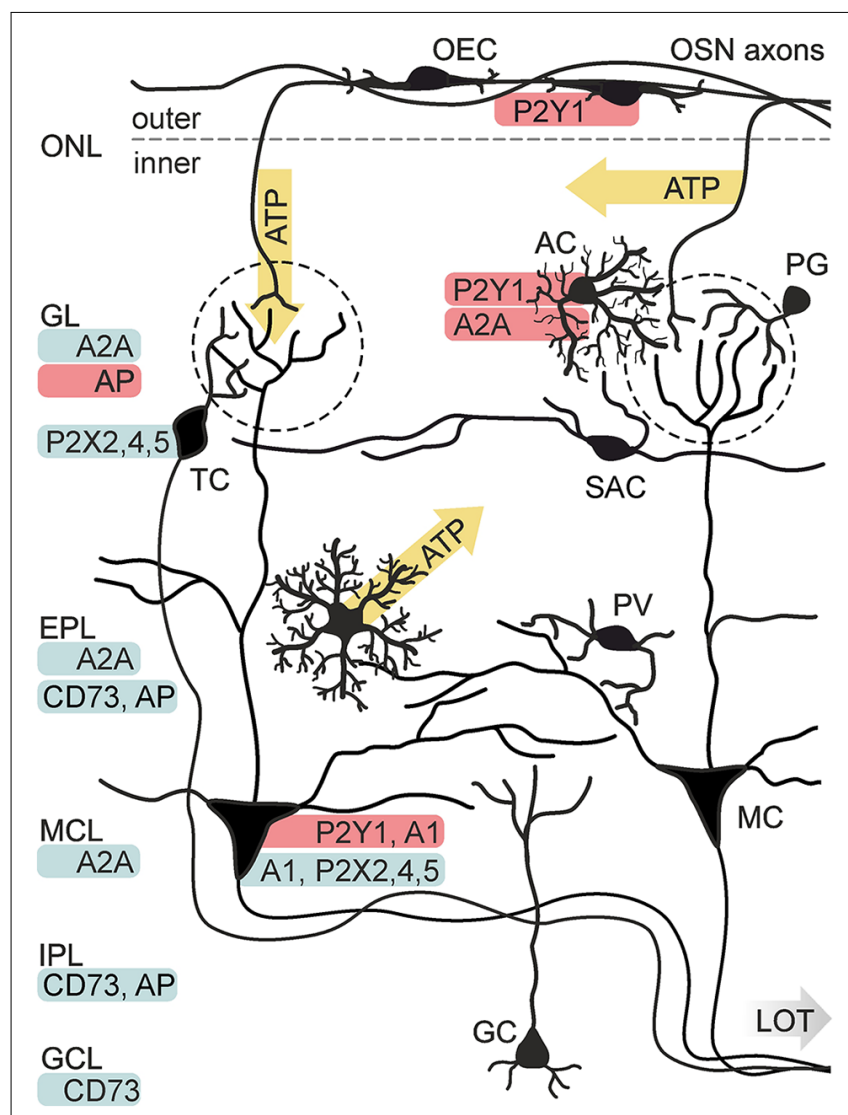

FIGURE 3 | Purinergic signaling in the olfactory bulb. Known release sides of purines (yellow) and distribution (red: physiological data, blue: histological data) of purinoceptors and degrading enzymes in the cellular network of the olfactory bulb. Electrical stimulation of axons of olfactory sensory neurons (OSN) results in the release of ATP from axon terminals in the GL and alongside the axons in the ONL. ATP is released from astrocytes (AC) via the opening of connexin 43 hemichannels. $\mathrm{P} 2 \mathrm{X}_{2 / 4 / 5}$ receptors have been identified histologically in mitral cells (MC) and tufted cells (TC). Physiological evidence exists for the expression of $\mathrm{P}_{2} \mathrm{Y}_{1}$ receptors in $\mathrm{AC}$ and $\mathrm{MC}$, as well as for $A_{1}$ receptor expression in $M C$ and $A_{2 A}$ receptor expression in $A C$. Expression of the $A_{2 A}$ receptor has been shown histologically for the GL, EPL and mitral cell layer (MCL). Activity of nucleotide-degrading enzymes alkaline phosphatase (AP) and ecto 5'-nucleotidase (CD73) has been demonstrated in several layers. Abbr.: GC, granule cell; GCL, granule cell layer; IPL, internal plexiform layer; LOT, lateral olfactory tract; OEC, olfactory ensheathing cell; PG, periglomerular neuron; PV, parvalbumin-positive neuron; SAC, short axon cell. Illustration by SciGraphics.

their axons into the olfactory bulb and form synapses with mitral and tufted cells.

\section{PURINERGIC SIGNALING IN THE OLFACTORY BULB}

\section{Purinoceptor Expression}

With a growing number of studies showing the influence of purinergic signaling in olfaction, a widespread involvement of purinoceptors in this sensory system becomes obvious. By now, the presence of purinoceptors has been shown for all layers of the olfactory bulb by means of physiological studies, antibody staining, in situ hybridization and binding studies with radiolabeled receptor ligands (Figure 3). $\mathrm{P} 2 \mathrm{X}_{2}, \mathrm{P} 2 \mathrm{X}_{4}, \mathrm{P} 2 \mathrm{X}_{5}$ and $\mathrm{P} 2 \mathrm{X}_{6}$ receptor expression has been demonstrated in the principal neurons of the olfactory bulb, mitral and tufted cells, by in situ hybridization and immunolabeling, while $\mathrm{P} 2 \mathrm{X}$ receptors have so far not been found in glial cells of the olfactory bulb (Collo et al., 1996; Vulchanova et al., 1996; Lê et al., 1998; Guo et al., 2008; Kaneda et al., 2010). For the family of P2Y receptors, only little information about expression in the olfactory bulb is published. Staining with a radio-labeled $\mathrm{P} 2 \mathrm{Y}_{1}$ ligand showed positive results for all layers of the olfactory bulb, with a pronounced staining in the glomerular layer (Simon et al., 1997). In olfactory bulb tissue, mRNA expression of all four types of adenosine receptors has been demonstrated by Northern blot (Mahan et al., 1991; Dixon et al., 1996). $A_{1}$ receptors, as well as $A_{2 A}$ receptors have been found by in situ hybridization and antibody staining (Johansson et al., 1997; Rosin et al., 1998; Kaelin-Lang et al., 1999). Noteworthy, the expression levels of $A_{1}$ and $A_{2 A}$ were among the highest in the entire mouse brain. In the olfactory bulb mRNA of $A_{1}$ receptors is predominantly expressed in a pattern resembling the localization, size and abundance of mitral and tufted cells (Rotermund et al., 2018). In situ hybridization depicts a more widespread expression of the $\mathrm{A}_{2 \mathrm{~A}}$ receptor, with intense staining in mitral and tufted cells, but also in periglomerular interneurons and granule cells (Rotermund et al., 2018).

\section{Glial Cell Physiology and Function}

Purinergic signaling in the olfactory bulb has first been described in glial cells, corroborating the important role of purines for neuron-glia interaction. Olfactory ensheathing cells, exclusively found in the olfactory nerve including the olfactory bulb nerve layer, respond to application of ATP with a $\mathrm{P}_{2} \mathrm{Y}_{1}$-mediated calcium increase in neonates (Rieger et al., 2007; Thyssen et al., 2010) as well as in adults (Thyssen et al., 2013; Stavermann et al., 2015). In contrast, application of adenosine has no impact on calcium levels in these cells (Thyssen et al., 2013). A recent study demonstrates that the observed effect of $\mathrm{P}_{2} \mathrm{Y}_{1}$-mediated calcium signaling is restricted to P75 neurotrophin receptorpositive olfactory ensheathing cells of the outer nerve layer, whereas P75-negative olfactory ensheathing cells of the inner nerve layer do not generate calcium signals in response to ATP or other purinergic ligands (Thyssen et al., 2013; Stavermann et al., 2015). Like most other neurotransmitter-mediated calcium responses in glial cells, the $\mathrm{P}_{2} \mathrm{Y}_{1}$-mediated intracellular calcium increase in olfactory ensheathing cells is based on calcium release driven by IP3 receptors, being amplified by calcium-induced calcium release and prolonged by store-operated calcium entry (Stavermann et al., 2012; Thyssen et al., 2013).

In addition to olfactory ensheathing cells, olfactory bulb astrocytes express purinoceptors. Periglomerular astrocytes have been shown to possess $\mathrm{P}_{2} \mathrm{Y}_{1}$ and $\mathrm{A}_{2} \mathrm{~A}$ receptors that are linked to intracellular calcium signaling (Doengi et al., 2008; Lohr and Deitmer, 2010). ATP, which is co-released with glutamate at axon terminals of olfactory sensory neurons, is degraded extracellularly to ADP and adenosine. It was shown that both $\mathrm{ADP}$ and adenosine elicit a rise in intracellular calcium levels in olfactory bulb astrocytes, mediated by $\mathrm{P}_{2} \mathrm{Y}_{1}$ and $\mathrm{A}_{2 \mathrm{~A}}$ receptors, 
while the co-released glutamate activates metabotropic glutamate receptor $5\left(\mathrm{mGluR}_{5}\right)$ and calcium-permeable AMPA receptors in these cells (Petzold et al., 2008; Verkhratsky et al., 2009; Droste et al., 2017). Calcium signaling evoked by $\mathrm{mGluR}_{5}$ activation is only found in astrocytes of developing animals, while the $\mathrm{P}_{2} \mathrm{Y}_{1^{-}}, \mathrm{A}_{2 \mathrm{~A}^{-}}$and AMPA receptor-evoked calcium responses persist in adults (Doengi et al., 2008; Otsu et al., 2015; Droste et al., 2017; Beiersdorfer et al., 2019). In accordance with calcium signaling in olfactory ensheathing cells, ATP- and ADP-evoked rises in intracellular calcium in olfactory bulb astrocytes are driven by calcium release via IP3 signaling and subsequent calcium entry by the activation of store-operated calcium channels (Singaravelu et al., 2006; Doengi et al., 2009). Interestingly, the calculated EC50 $(4.5 \mu \mathrm{M})$ for ADP-induced calcium signaling in glomerular astrocytes is higher by more than one order of magnitude compared to the EC50 value $(0.23 \mu \mathrm{M})$ for $\mathrm{A}_{2 \mathrm{~A}}$ receptor-dependent calcium signals (Doengi et al., 2008). This concentration-dependent activation may result in a differentiated activation of purinergic receptors: only high amounts of ATP above $1 \mu \mathrm{M}$ are sufficient to activate $\mathrm{P}_{2} \mathrm{Y}_{1}$ receptors in glomerular astrocytes, whereas lower amounts of ATP bypass $\mathrm{P} 2$ receptor activation and directly target adenosinergic $\mathrm{P} 1$ receptors providing the possibility of graduated responses to different neuronal activity.

In other brain areas, astrocytes have been shown to respond to neurotransmitters released from presynaptic terminals with increases in the cytosolic calcium concentration, which can result in release of so-called gliotransmitters (e.g., glutamate, D-serin and ATP) and other substances such as arachidonic acid and prostaglandins which affect adjacent synapses and blood vessels (Haydon and Carmignoto, 2006; Attwell et al., 2010; Verkhratsky et al., 2012; Shigetomi et al., 2016; Dallérac et al., 2018). Calcium-dependent modulation of blood vessels by astrocytes upon neuronal activity is called neurovascular coupling and has also been studied in the olfactory bulb (Petzold et al., 2008; Doengi et al., 2009; Lohr et al., 2011; Otsu et al., 2015). Neurovascular coupling is an important mechanism to cope with the increasing energy demand upon neuronal activity, since action potential firing and synaptic transmission are the main energy sinks in the brain (Attwell and Laughlin, 2001; Attwell and Gibb, 2005; Barros and Deitmer, 2010). In addition, neurovascular coupling regulates and stabilizes the blood pressure in brain arterioles (Iadecola and Nedergaard, 2007). In olfactory bulbs of living, anesthetized mice, odor stimulation evokes $\mathrm{mGluR}_{5}$ - and $\mathrm{P} 2 \mathrm{Y}_{1} / \mathrm{A}_{2 \mathrm{~A}}$-dependent calcium signaling in astrocytes that trigger dilation of adjacent capillaries and hyperemia (Petzold et al., 2008; Otsu et al., 2015). However, since $\mathrm{mGluR}_{5}$ is down-regulated in astrocytes of the cortex and the olfactory bulb in adult mice, glial $\mathrm{mGluR}_{5}$ is unlikely to mediate neurovascular coupling in adult animals (Sun et al., 2013; Otsu et al., 2015; Beiersdorfer et al., 2019). In contrast, calcium signaling evoked by ATP and possibly ADP and adenosine persists from neonates to adults (Doengi et al., 2008; Beiersdorfer et al., 2019), resulting in astrocytic calcium responses upon odor stimulation even in the absence of $\mathrm{mGluR}_{5}$ (Otsu et al., 2015). Calcium transients in astrocytic microdomains of perivascular endfeet are followed by a drop in calcium in perivascular pericytes and, finally, vasodilation as well as hyperemia in the glomerular layer (Otsu et al., 2015; Rungta et al., 2018). The olfactory nerve layer comprises axons of olfactory sensory neurons and olfactory ensheathing cells but lacks astrocytes with the exception of astrocytic processes that enwrap arterioles that penetrate the nerve layer. Calcium signaling in astrocytes around penetrating arterioles is able to mediate neurovascular coupling (Petzold et al., 2008), however, capillaries in the nerve layer require a different mechanism to adapt to neuronal activity. Capillaries in the nerve layer are enwrapped by the fine processes of olfactory ensheathing cells (Thyssen et al., 2010). Olfactory ensheathing cells express $\mathrm{mGluR}_{1}$ as well as $\mathrm{P} 2 \mathrm{Y}_{1}$ receptors and respond to glutamate and ATP released from axons of sensory neurons with calcium transients (Rieger et al., 2007; Thyssen et al., 2010, 2013). Similar to astrocytes, mGluRs are down-regulated during the first postnatal weeks, whereas purinoceptor expression persists until adulthood (Thyssen et al., 2013; Stavermann et al., 2015; Beiersdorfer et al., 2019). Neuronal activity, local stimulation of $\mathrm{P}_{2} \mathrm{Y}_{1}$ receptors and induction of calcium signaling in single olfactory ensheathing cells trigger vasoresponses in the olfactory bulb capillaries, indicating that in addition to astrocytes, olfactory ensheathing cells are able to mediate neurovascular coupling via purinergic signaling (Thyssen et al., 2010; Lohr et al., 2011, 2014; Beiersdorfer et al., 2019).

\section{Neuromodulation}

ATP and its breakdown products ADP and adenosine have been described as neuromodulators in many instances (Chen et al., 2014; Sebastião and Ribeiro, 2015; Guzman and Gerevich, 2016; Köles et al., 2016; Boué-Grabot and Pankratov, 2017). In developing as well as mature olfactory bulbs, ATP increases neuronal network activity leading to excitation of output neurons, the mitral and tufted cells (Fischer et al., 2012; Schulz, 2018). In these studies, wide-field photoapplication of ATP (by photolysis of caged ATP) evokes an increase of synaptic inputs and excitation of mitral cells, measured as whole-cell current and voltage responses. In addition, local release of ATP by photoapplication in a single glomerulus produces an increase of synaptic inputs in the mitral cell which is accompanied by an increase in intracellular calcium in the mitral cell tuft (Fischer et al., 2012). The ATP response depends on the activation of $\mathrm{P}_{2} \mathrm{Y}_{1}$ receptors, as inhibition of $\mathrm{P}_{2} \mathrm{Y}_{1}$ receptors by the specific antagonist MRS2179 impeded the effect. The rise in network activity is not the consequence of direct $\mathrm{P}_{2} \mathrm{Y}_{1}$-mediated excitation of the mitral cell itself, but of other neurons, since suppression of neuronal firing with TTX and inhibition of NMDA and AMPA receptors, respectively, not only abolished the network response but also eliminated $\mathrm{P}_{2} \mathrm{Y}_{1}$-mediated current responses in mitral cells almost entirely (Fischer et al., 2012). So far, the identity of these $\mathrm{P}_{2} \mathrm{Y}_{1}$-expressing neurons has not been resolved. Despite the high expression of $\mathrm{P} 2 \mathrm{X}$ receptors in mitral and tufted cells, as shown by in situ hybridization and immunolabeling (Lê et al., 1998; Kanjhan et al., 1999; Guo et al., 2008), P2X-mediated currents could not be measured yet (Figure 3). In summary, the studies show that purinoceptors are abundant 

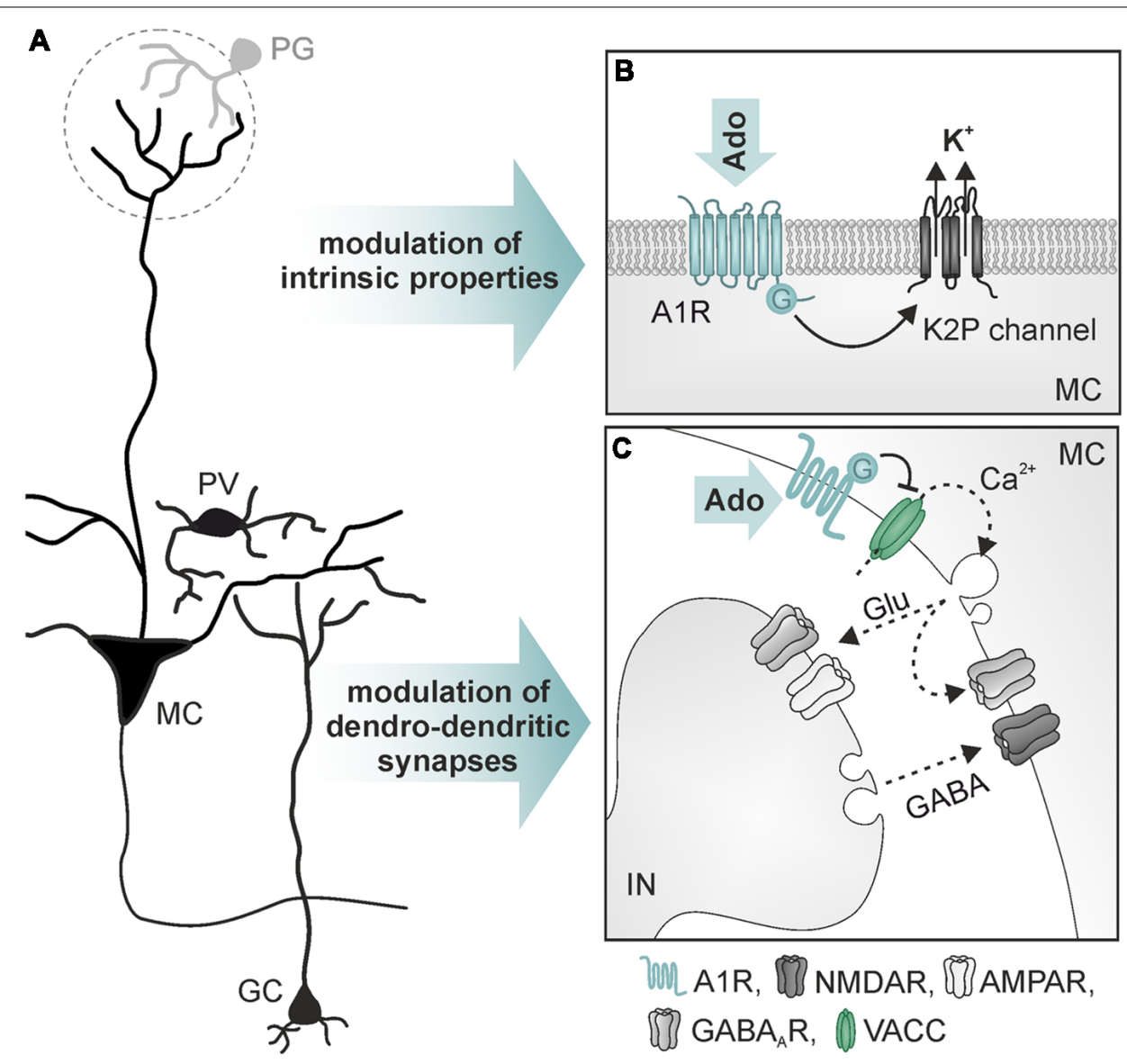

FIGURE 4 | Mechanisms of action of adenosine in mitral cells. (A) Simplified neuronal network in the olfactory bulb. (B) Opening of two-pore domain potassium channels (K2P) by activation of $A_{1}$ receptors leads to hyperpolarization of mitral cells (MC). (C) $A_{1}$ receptor-mediated reduction of $\mathrm{Ca}^{2+}$ influx into presynaptic sites of MC reduces dendro-dendritic inhibition at reciprocal synapses between $\mathrm{MC}$ and interneurons (IN; GC and parvalbumin-positive interneurons). Abbr.: Ado, adenosine; Glu, glutamate; GC, granule cells; PG, periglomerular interneuron; PV, parvalbumin-positive interneuron; VACC, voltage-activated calcium channel. Illustration by SciGraphics.

in the olfactory bulb and ATP has a strong excitatory effect on neuronal network activity, however, the exact mechanisms by which ATP modulates neuronal performance still need to be elucidated.

A well-established role of adenosine is the regulation of glutamatergic synaptic transmission by activation of presynaptic P1 receptors (Sebastião and Ribeiro, 2009; Chen et al., 2014). In the olfactory bulb, $A_{1}$ and $A_{2 A}$ receptors are highly expressed (Kaelin-Lang et al., 1999; Rotermund et al., 2018). In addition, the activity of ATP-degrading ectoenzymes required for the production of adenosine from ATP is among the highest activities found in the rodent brain (Langer et al., 2008). It has been shown that adenosine acts as a neuromodulator in the olfactory bulb (Roux et al., 2015; Rotermund et al., 2018; Schulz et al., 2018; Figure 4). Whole cell patch clamp recordings show that activation of $A_{1}$ receptors hyperpolarizes mitral cells and reduces the network activity in olfactory bulb brain slice preparations of wild type mice, but not of $A_{1}$ receptor knockout mice (Rotermund et al., 2018). The hyperpolarization is mediated by increasing the potassium conductance of the mitral cell membrane. While in other brain areas, $A_{1}$ receptor activation leads to stimulation of $\mathrm{G}$ protein-coupled inwardly rectifying potassium (GIRK) channels (Sickmann and Alzheimer, 2003; Kim and Johnston, 2015), the effect of adenosine on mitral cells is based on an $A_{1}$ receptor-dependent opening of two-pore domain potassium channels (Figure 4B), probably reflecting very ancient cellular mechanisms in this archicortex (Rotermund et al., 2018). Roux et al. (2015) found constitutive release of ATP from astrocytes that is degraded to adenosine, resulting in DPCPX-sensitive alteration of slow membrane oscillations of mitral cells. In another study, DPCPX had no effect on steadystate excitability of mitral cells but inhibited adenosine-evoked hyperpolarization (Rotermund et al., 2018). The adenosineevoked hyperpolarization is associated with a decrease in spontaneous action potential firing. In contrast, bursting activity of mitral cells upon synaptic input from sensory fibers is unaffected by adenosine, indicating lack of adenosine-mediated plasticity at synapses between sensory neurons and mitral cells (Rotermund et al., 2018). This results in a significant increase in the ratio of synaptically evoked firing over spontaneous firing 
and hence, in the signal-to-noise ratio of the output signaling of mitral cells (Rotermund et al., 2018).

Mitral and tufted cells establish numerous reciprocal dendrodendritic synapses between their lateral dendrites and inhibitory interneurons (Figure 4C), mainly granule cells and parvalbuminpositive cells (Crespo et al., 2013). Mitral cells express $A_{1}$ receptors that are located in the presynaptic membrane of the mitral-to-interneuron synaptic connection of these reciprocal synapses. Activation of $\mathrm{A}_{1}$ receptors inhibits presynaptic voltagedependent calcium channels of the $\mathrm{N}$ - and P/Q-type, thus reducing glutamate release from mitral cell lateral dendrites (Schulz et al., 2018). Consequently, interneurons receive less excitation and thus respond with diminished GABA release, resulting in attenuated recurrent inhibition in mitral cells. The attenuation of NMDA, as well as AMPA receptor-mediated dendro-dendritic inhibition, indicates that reciprocal synapses of mitral cells with both, granule cells (NMDA receptor-driven) and with parvalbumin-positive cells (AMPA receptor-driven), are modulated by adenosine (Schulz et al., 2018). Recurrent inhibition between mitral cells and GABAergic interneurons is fundamental for odor discrimination. Increasing recurrent inhibition by, for instance, optogenetic excitation of granule cells or enhanced GABA release from granule cells due to ablation of GluA2 subunits (thereby amplifying glutamate-evoked calcium influx) improves odor discrimination, whereas inhibition of granule cells impairs odor discrimination (Abraham et al., 2010; Gschwend et al., 2015). Consequently, $A_{1}$ receptor-deficient mice that lack adenosine-mediated depression of recurrent inhibition outperform wild type mice in a behavioral olfaction test, emphasizing the role of adenosine in olfactory information processing (Schulz et al., 2018).

\section{PURINERGIC SIGNALING IN THE OLFACTORY CORTEX}

\section{Expression of Purinoceptors and Nucleotidases}

As already known for many years, adenosine modulates synaptic transmission in the olfactory cortex (Kuroda, 1978;

A

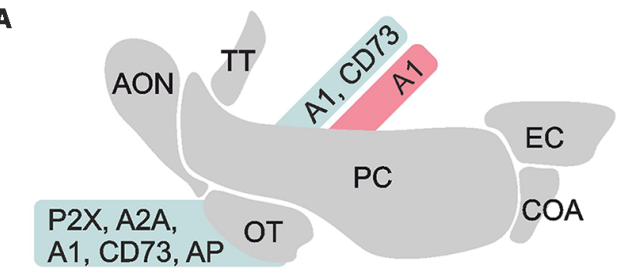

B

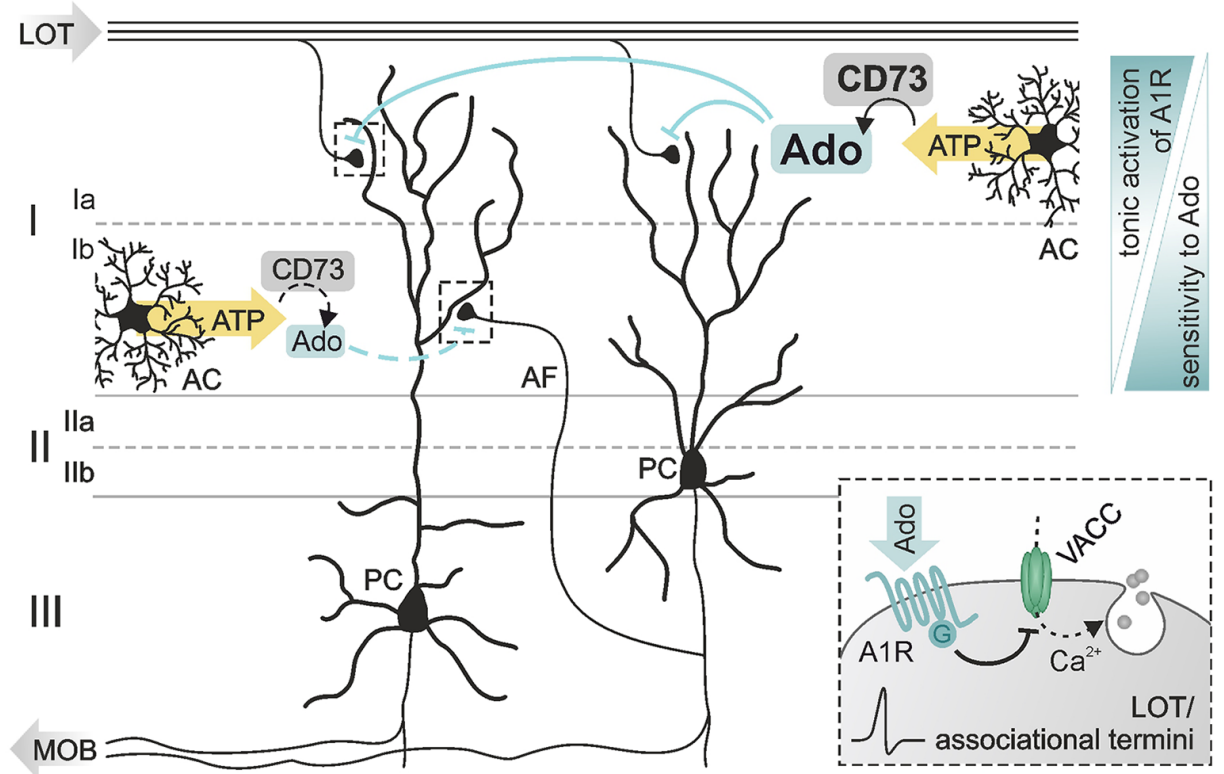

FIGURE 5 | Purinergic modulation in the piriform cortex. (A) Expression of members of the purinergic signaling pathway in the olfactory cortex documented by physiological (red) and histological (blue) data. (B) Pyramidal cells (PC) reside in layer II/III of the piriform cortex with dendritic arbors spreading in superficial layer I. Synaptic inputs at PC dendrites are segregated in distinct sublayers, sublayer la exclusively receiving excitatory input from fibers of the LOT, sublayer Ib receiving input from intracortical associational fibers (AF). Adenosine affects both types of inputs by A1 receptor-dependent inhibition of presynaptic voltage-activated calcium channels (VACC) and thereby inhibition of glutamate release (see inset). Ecto $5^{\prime}$-nucleotidase (CD73) is differentially expressed in the sublayers resulting in higher basal levels of extracellular adenosine in layer la compared to layer lb. Synaptic transmission in both layers shows different sensitivity to adenosine, associative synapses in layer Ib being more sensitive to adenosine than LOT synapses in layer la. Abbr.: AC, astrocyte; MOB, main olfactory bulb. Illustration by SciGraphics. 
Scholfield, 1978; Okada and Kuroda, 1980; Collins and Anson, 1985) There is a number of studies demonstrating the expression of enzymes and receptors of the purinergic signaling cascade in the primary olfactory cortex (Figure 5A). Kidd et al. (1995) detected P2X receptor mRNA in the olfactory tubercle, implying a contribution of ATP to fast neurotransmission in this brain area. The majority of available data, though, concerns adenosinergic signaling. In the olfactory tubercle, the expression of adenosine $\mathrm{A}_{2 \mathrm{~A}}$ receptors is the highest apart from expression in the striatum and the olfactory bulb as shown by in situ hybridization, antibody staining and autoradiographic labeling studies (Johansson and Fredholm, 1995; Luthin et al., 1995; Rosin et al., 1998, 2003; DeMet and Chicz-DeMet, 2002; Rotermund et al., 2018). A $A_{1}$ receptors are also expressed in the olfactory tubercle, albeit to a lesser degree (Fastbom et al., 1987; Rotermund et al., 2018). Antibody staining of the ecto-nucleotidase CD73 clearly labels the olfactory tubercle (Kulesskaya et al., 2013). Furthermore, enzymatic activity of ecto $5^{\prime}$-nucleotidases and alkaline phosphatase is very high in the olfactory tubercle, emphasizing the role of purinergic neurotransmission and -modulation in this brain area (Langer et al., 2008).

\section{Modulation of Synaptic Plasticity}

Expression of $A_{1}$ receptors and ecto $5^{\prime}$-nucleotidases has been found in the piriform cortex, pointing to a role of adenosine in neuromodulation (Goodman and Synder, 1982; Trieu et al., 2015). The main targets of adenosinergic modulation in the piriform cortex are excitatory synaptic inputs in pyramidal cell dendrites (Rezvani et al., 2007; Yang et al., 2007; Trieu et al., 2015; Perrier et al., 2019). The somata of pyramidal cells reside in layer II/III of the piriform cortex, while their apical dendritic arbors extend into the superficial layer I (Figure 5B). There they receive spatially segregated excitatory input from different sources: axons of mitral cells carry odor information via the lateral olfactory tract and synapse on pyramidal cell dendrites in layer Ia (Figure 5B, LOT), while intrinsic afferent fibers from piriform cortex pyramidal cells and other cortical areas (forming the piriform cortex association network) establish synapses with pyramidal cell dendrites in layer Ib (Figure 5B, AF; Luskin and Price, 1983a,b; Nevill and Haberly, 2004). Stimulation of lateral olfactory tract fibers evokes field excitatory postsynaptic potentials (fEPSP) in the piriform cortex with a characteristic bipolar waveform reflecting the two different kinds of input in pyramidal cells (Haberly, 1973). The initial peak represents the monosynaptic sensory transmission (lateral olfactory tract-to-pyramidal cell), followed by a compound signal representing the activity of associational network fibers within the piriform cortex (pyramidal cellto-pyramidal cell). Both types of synapses are modulated by adenosine; in in vivo experiments, activation of $\mathrm{A}_{1}$ receptors has been shown to reduce both the initial peak as well as the subsequent compound signal of the fEPSP (Rezvani et al., 2007). This depression of synaptic transmission is mediated by $A_{1}$ receptor-dependent inhibition of presynaptic voltagegated calcium entry via $\mathrm{N}$ - and $\mathrm{P} / \mathrm{Q}$-type calcium channels
(Yang et al., 2007). In addition, adenosine increases pairedpulse facilitation in layer Ia while decreasing paired-pulse depression in layer Ib (Yang et al., 2007). Hence, $A_{1}$ receptormediated inhibition of calcium channels decreases the release probability at these synapses. Interestingly, synapses between associational network fibers and pyramidal cells in layer Ib are more sensitive for modulation by experimentally added adenosine compared to synapses between lateral olfactory tract fibers and pyramidal cells in layer Ia, indicating a lower concentration of endogenous adenosine in layer $\mathrm{Ib}$ (Yang et al., 2007). The low ambient adenosine concentration at layer Ib synapses results from slow ATP-to-adenosine conversion due to low abundance of ecto $5^{\prime}$-nucleotidase and lack of synaptic ensheathment by glial cell processes, which provide one major source of ATP in the cortex (Haberly and Behan, 1983; Nevill and Haberly, 2004; Pankratov and Lalo, 2015; Trieu et al., 2015; Yi et al., 2017). Synapses between lateral olfactory tract fibers and pyramidal cell dendrites in layer Ia are not only depressed by adenosine, but can also be facilitated dependent on the frequency of synaptic activation (Perrier et al., 2019). While adenosine has no effect on the amplitude of fEPSP evoked by a train of stimuli at frequencies between 3 and $25 \mathrm{~Hz}$, it strongly facilitates fEPSP at frequencies between 50 and $100 \mathrm{~Hz}$ (Perrier et al., 2019). Since the entire range of stimulation frequencies used in that study reflects frequencies naturally occurring during odor perception depending on, e.g., odor concentrations, adenosine might fine-tune odor perception in an intensity-dependent manner. However, while the studies above clearly demonstrate neuromodulatory functions of adenosine in synaptic transmission and plasticity in the olfactory cortex, its role in olfactory learning and memory formation remains to be shown.

\section{CONCLUSION}

Purinergic signaling is a universal and versatile system of neurotransmission and -modulation. The extraordinary high expression of purinoceptors and nucleotide-degrading enzymes in regions of the olfactory pathway such as the olfactory bulb and olfactory tubercle emphasize the significance of purinergic signaling for this sensory system. $\mathrm{P} 2 \mathrm{X}, \mathrm{P} 2 \mathrm{Y}$ and adenosine receptors are involved in adult neurogenesis in the olfactory epithelium, link neuronal activity to vascular responses in the olfactory bulb and modulate synaptic transmission in the olfactory bulb as well as the olfactory cortex. However, research on the functional role of purinergic signaling in olfaction has only started recently. Based on the recent physiological studies that reveal a broad range of specific purinoceptordependent effects, further research faces the challenge to link these findings to olfactory perception and behavior. In addition, given the fact that olfactory impairment is an early symptom in many neurodegenerative and neuroinflammatory diseases, the involvement of purinergic signaling in neuronal degeneration in the olfactory system is expected to move into focus in the future. The use of cell-specific knockout 
animals in combination with disease models and behavioral tests might be a promising strategy to gain insights into the mechanisms of purinergic neuromodulation in health and disease.

\section{AUTHOR CONTRIBUTIONS}

$\mathrm{NR}, \mathrm{DH}$ and $\mathrm{CL}$ wrote the text. KS designed the figures. All authors edited the manuscript.

\section{REFERENCES}

Abbracchio, M. P., Burnstock, G., Boeynaems, J. M., Barnard, E. A., Boyer, J. L., Kennedy, C., et al. (2006). International Union of Pharmacology LVIII: update on the P2Y G protein-coupled nucleotide receptors: from molecular mechanisms and pathophysiology to therapy. Pharmacol. Rev. 58, 281-341. doi: $10.1124 /$ pr.58.3.3

Abbracchio, M. P., Burnstock, G., Verkhratsky, A., and Zimmermann, H. (2009). Purinergic signalling in the nervous system: an overview. Trends Neurosci. 32, 19-29. doi: 10.1016/j.tins.2008.10.001

Abraham, N. M., Egger, V., Shimshek, D. R., Renden, R., Fukunaga, I., Sprengel, R., et al. (2010). Synaptic inhibition in the olfactory bulb accelerates odor discrimination in mice. Neuron 65, 399-411. doi: 10.1016/j.neuron.2010.01.009

Attwell, D., Buchan, A. M., Charpak, S., Lauritzen, M., MacVicar, B. A., and Newman, E. A. (2010). Glial and neuronal control of brain blood flow. Nature 468, 232-243. doi: 10.1038 /nature 09613

Attwell, D., and Gibb, A. (2005). Neuroenergetics and the kinetic design of excitatory synapses. Nat. Rev. Neurosci. 6, 841-849. doi: 10.1038/nrn1784

Attwell, D., and Laughlin, S. B. (2001). An energy budget for signaling in the grey matter of the brain. J. Cereb. Blood Flow Metab. 21, 1133-1145. doi: 10.1097/00004647-200110000-00001

Bagatini, M. D., Dos Santos, A. A., Cardoso, A. M., Manica, A., Reschke, C. R., and Carvalho, F. B. (2018). The impact of purinergic system enzymes on noncommunicable, neurological and degenerative diseases. J. Immunol. Res. 2018:4892473. doi: $10.1155 / 2018 / 4892473$

Barros, L. F., and Deitmer, J. W. (2010). Glucose and lactate supply to the synapse. Brain Res. Rev. 63, 149-159. doi: 10.1016/j.brainresrev.2009.10.002

Beiersdorfer, A., Scheller, A., Kirchhoff, F., and Lohr, C. (2019). Panglial gap junctions between astrocytes and olfactory ensheathing cells mediate transmission of $\mathrm{Ca}^{2+}$ transients and neurovascular coupling. Glia doi: 10.1002/ glia.23613 [Epub ahead of print].

Berkowicz, D. A., Trombley, P. Q., and Shepherd, G. M. (1994). Evidence for glutamate as the olfactory receptor cell neurotransmitter. J. Neurophysiol. 71, 2557-2561. doi: 10.1152/jn.1994.71.6.2557

Bodin, P., and Burnstock, G. (2001). Purinergic signalling: ATP release. Neurochem. Res. 26, 959-969. doi: 10.1023/A:1012388618693

Boison, D. (2013). Adenosine kinase: exploitation for therapeutic gain. Pharmacol. Rev. 65, 906-943. doi: 10.1124/pr.112.006361

Boison, D., Chen, J. F., and Fredholm, B. B. (2010). Adenosine signaling and function in glial cells. Cell Death Differ. 17, 1071-1082. doi: 10.1038/cdd. 2009.131

Boué-Grabot, E., and Pankratov, Y. (2017). Modulation of central synapses by astrocyte-released ATP and postsynaptic P2X receptors. Neural Plast. 2017:9454275. doi: 10.1155/2017/9454275

Brann, J. H., and Firestein, S. J. (2014). A lifetime of neurogenesis in the olfactory system. Front. Neurosci. 8:182. doi: 10.3389/fnins.2014.00182

Burnstock, G. (2013). Introduction to purinergic signalling in the brain. Adv. Exp. Med. Biol. 986, 1-12. doi: 10.1007/978-94-007-4719-7_1

Burnstock, G., Campbell, G., Satchell, D., and Smythe, A. (1970). Evidence that adenosine triphosphate or a related nucleotide is the transmitter substance released by non-adrenergic inhibitory nerves in the gut. Br. J. Pharmacol. 40, 668-688. doi: 10.1111/j.1476-5381.1970.tb10646.x

Burnstock, G., Fredholm, B. B., and Verkhratsky, A. (2011). Adenosine and ATP receptors in the brain. Curr. Top. Med. Chem. 11, 973-1011. doi: $10.2174 / 156802611795347627$

\section{FUNDING}

The research that served as basis for this review article was financed by the Deutsche Forschungsgemeinschaft (HI 1288/3; LO 779/6; LO 779/10; SFB 1328-TP07 and -TP16).

\section{ACKNOWLEDGMENTS}

We thank SciGraphics (contact@scigraphics.de) for contributing the illustrations.

Burnstock, G., and Verkhratsky, A. (2009). Evolutionary origins of the purinergic signalling system. Acta Physiol. 195, 415-447. doi: 10.1111/j.1748-1716.2009. 01957.x

Chen, J. F., Lee, C. F., and Chern, Y. (2014). Adenosine receptor neurobiology: overview. Int. Rev. Neurobiol. 119, 1-49. doi: 10.1016/B978-0-12-801022-8. 00001-5

Clemow, D. B., and Brunjes, P. C. (1996). Development of 5'-nucleotidase staining in the olfactory bulbs of normal and naris-occluded rats. Int. J. Dev. Neurosci. 14, 901-911. doi: 10.1016/s0736-5748(96)00040-8

Collins, G. G., and Anson, J. (1985). Adenosine A1 receptors mediate the inhibitory effects of exogenous adenosine in the rat olfactory cortex slice. Neuropharmacology 24, 1077-1084. doi: 10.1016/0028-3908(85) 90195-9

Collo, G., North, R. A., Kawashima, E., MerloPich, E., Neidhart, S., Surprenant, A., et al. (1996). Cloning of $\mathrm{P} 2 \mathrm{X}_{5}$ and $\mathrm{P}_{2} \mathrm{X}_{6}$ receptors and the distribution and properties of an extended family of ATP-gated ion channels. J. Neurosci. 16, 2495-2507. doi: 10.1523/JNEUROSCI.16-08-02495.1996

Courtiol, E., and Wilson, D. A. (2017). The olfactory mosaic: bringing an olfactory network together for odor perception. Perception 46, 320-332. doi: $10.1177 / 0301006616663216$

Crespo, C., Liberia, T., Blasco-Ibanez, J. M., Nacher, J., and Varea, E. (2013). The circuits of the olfactory bulb. The exception as a rule. Anat. Rec. 296, 1401-1412. doi: 10.1002/ar.22732

Czesnik, D., Kuduz, J., Schild, D., and Manzini, I. (2006). ATP activates both receptor and sustentacular supporting cells in the olfactory epithelium of Xenopus laevis tadpoles. Eur. J. Neurosci. 23, 119-128. doi: 10.1111/j.14609568.2005.04533.x

Dallérac, G., Zapata, J., and Rouach, N. (2018). Versatile control of synaptic circuits by astrocytes: where, when and how? Nat. Rev. Neurosci. 19, 729-743. doi: 10.1038/s41583-018-0080-6

De Saint Jan, D., Hirnet, D., Westbrook, G. L., and Charpak, S. (2009). External tufted cells drive the output of olfactory bulb glomeruli. J. Neurosci. 29, 2043-2052. doi: 10.1523/jneurosci.5317-08.2009

De Saint Jan, D., and Westbrook, G. L. (2005). Detecting activity in olfactory bulb glomeruli with astrocyte recording. J. Neurosci. 25, 2917-2924. doi: 10.1523/JNEUROSCI.5042-04.2005

Deitmer, J. W., Verkhratsky, A. J., and Lohr, C. (1998). Calcium signalling in glial cells. Cell Calcium 24, 405-416. doi: 10.1016/s0143-4160(98)90063-x

DeMet, E. M., and Chicz-DeMet, A. (2002). Localization of adenosine A2A-receptors in rat brain with $\left[{ }^{3} \mathrm{H}\right] \mathrm{ZM}-241385$. Naunyn Schmiedebergs. Arch. Pharmacol. 366, 478-481. doi: 10.1007/s00210-002-0613-3

Dixon, A. K., Gubitz, A. K., Sirinathsinghji, D. J. S., Richardson, P. J., and Freeman, T. C. (1996). Tissue distribution of adenosine receptor mRNAs in the rat. Br. J. Pharmacol. 118, 1461-1468. doi: 10.1111/j.1476-5381.1996.tb15561.x

Doengi, M., Deitmer, J. W., and Lohr, C. (2008). New evidence for purinergic signaling in the olfactory bulb: $\mathrm{A}_{2 \mathrm{~A}}$ and $\mathrm{P}_{2} \mathrm{Y}_{1}$ receptors mediate intracellular calcium release in astrocytes. FASEB J. 22, 2368-2378. doi: 10.1096/fj.07101782

Doengi, M., Hirnet, D., Coulon, P., Pape, H.-C., Deitmer, J. W., and Lohr, C. (2009). GABA uptake-dependent $\mathrm{Ca}^{2+}$ signaling in developing olfactory bulb astrocytes. Proc. Natl. Acad. Sci. U S A 106, 17570-17575. doi: 10.1073/pnas. 0809513106

Droste, D., Seifert, G., Seddar, L., Jadtke, O., Steinhauser, C., and Lohr, C. (2017). $\mathrm{Ca}^{2+}$-permeable AMPA receptors in mouse olfactory bulb astrocytes. Sci. Rep. 7:44817. doi: $10.1038 /$ srep44817 
Edwards, F. A., Gibb, A. J., and Colquhoun, D. (1992). ATP receptor-mediated synaptic currents in the central nervous system. Nature 359, 144-147. doi: $10.1038 / 359144 \mathrm{a} 0$

Ennis, M., Zimmer, L. A., and Shipley, M. T. (1996). Olfactory nerve stimulation activates rat mitral cells via NMDA and non-NMDA receptors in vitro. Neuroreport 7, 989-992. doi: 10.1097/00001756-199604100-00007

Evans, R. J., Derkach, V., and Surprenant, A. (1992). ATP mediates fast synaptic transmission in mammalian neurons. Nature 357, 503-505. doi: $10.1038 / 357503 \mathrm{a} 0$

Fastbom, J., Pazos, A., Probst, A., and Palacios, J. M. (1987). Adenosine Al receptors in the human brain: a quantitative autoradiographic study. Neuroscience 22, 827-839. doi: 10.1016/0306-4522(87)92962-9

Fischer, T., Rotermund, N., Lohr, C., and Hirnet, D. (2012). P2Y 1 receptor activation by photolysis of caged ATP enhances neuronal network activity in the developing olfactory bulb. Purinergic Signal. 8, 191-198. doi: 10.1007/s11302-011-9286-Z

Fu, Z., Ogura, T., Luo, W., and Lin, W. (2018). ATP and odor mixture activate TRPM5-expressing microvillous cells and potentially induce acetylcholine release to enhance supporting cell endocytosis in mouse main olfactory epithelium. Front. Cell. Neurosci. 12:71. doi: 10.3389/fncel.2018.00071

Geiger, J. D., and Nagy, J. I. (1987). Ontogenesis of adenosine deaminase activity in rat brain. J. Neurochem. 48, 147-153. doi: 10.1111/j.1471-4159.1987. tb13139.x

Goodman, R. R., and Synder, S. H. (1982). Autoradiographic localization of adenosine receptors in rat brain using $\left[{ }^{3} \mathrm{H}\right]$ cyclohexyladenosine. J. Neurosci. 2, 1230-1241. doi: 10.1523/jneurosci.02-09-01230.1982

Gottfried, J. A. (2006). Smell: central nervous processing. Adv. Otorhinolaryngol. 63, 44-69. doi: 10.1159/000093750

Gschwend, O., Abraham, N. M., Lagier, S., Begnaud, F., Rodriguez, I., and Carleton, A. (2015). Neuronal pattern separation in the olfactory bulb improves odor discrimination learning. Nat. Neurosci. 18, 1474-1482. doi: 10.1038/ nn.4089

Guo, W., Xu, X., Gao, X., Burnstock, G., He, C., and Xiang, Z. (2008). Expression of P2X5 receptors in the mouse CNS. Neuroscience 156, 673-692. doi: 10.1016/j. neuroscience.2008.07.062

Guzman, S. J., and Gerevich, Z. (2016). P2Y receptors in synaptic transmission and plasticity: therapeutic potential in cognitive dysfunction. Neural Plast. 2016:1207393. doi: 10.1155/2016/1207393

Haberly, L. B. (1973). Summed potentials evoked in opossum prepyriform cortex. J. Neurophysiol. 36, 775-788. doi: 10.1152/jn.1973.36.4.775

Haberly, L. B. (2001). Parallel-distributed processing in olfactory cortex: new insights from morphological and physiological analysis of neuronal circuitry. Chem. Senses 26, 551-576. doi: 10.1093/chemse/26.5.551

Haberly, L., and Behan, M. (1983). Structure of the piriform cortex of the opossum. III. Ultrastructural characterization of synaptic terminals of association and olfactory bulb afferent fibers. J. Comp. Neurol. 219, 448-460. doi: 10.1002/cne. 902190406

Hassenklöver, T., Kurtanska, S., Bartoszek, I., Junek, S., Schild, D., and Manzini, I. (2008). Nucleotide-induced $\mathrm{Ca}^{2+}$ signaling in sustentacular supporting cells of the olfactory epithelium. Glia 56, 1614-1624. doi: 10.1002/glia.20714

Haydon, P. G., and Carmignoto, G. (2006). Astrocyte control of synaptic transmission and neurovascular coupling. Physiol. Rev. 86, 1009-1031. doi: 10.1152/physrev.00049.2005

Hayoz, S., Jia, C., and Hegg, C. C. (2012). Mechanisms of constitutive and ATP-evoked ATP release in neonatal mouse olfactory epithelium. BMC Neurosci. 13:53. doi: 10.1186/1471-2202-13-53

Hegg, C. C., Greenwood, D., Huang, W., Han, P., and Lucero, M. T. (2003). Activation of purinergic receptor subtypes modulates odor sensitivity. J. Neurosci. 23, 8291-8301. doi: 10.1523/jneurosci.23-2308291.2003

Hegg, C. C., Irwin, M., and Lucero, M. T. (2009). Calcium store-mediated signaling in sustentacular cells of the mouse olfactory epithelium. Glia 57, 634-644. doi: 10.1002/glia.20792

Hegg, C. C., Jia, C., Chick, W. S., Restrepo, D., and Hansen, A. (2010). Microvillous cells expressing IP3 receptor type 3 in the olfactory epithelium of mice. Eur. J. Neurosci. 32, 1632-1645. doi: 10.1111/j.1460-9568.2010.07449.x

Heydel, J. M., Coelho, A., Thiebaud, N., Legendre, A., Le Bon, A. M., Faure, P., et al. (2013). Odorant-binding proteins and xenobiotic metabolizing enzymes: implications in olfactory perireceptor events. Anat. Rec. 296, 1333-1345. doi: 10.1002/ar.22735

Holton, P. (1959). The liberation of adenosine triphosphate on antidromic stimulation of sensory nerves. J. Physiol. 145, 494-504. doi: 10.1113/jphysiol. 1959.sp006157

Housley, G. D., Bringmann, A., and Reichenbach, A. (2009). Purinergic signaling in special senses. Trends Neurosci. 32, 128-141. doi: 10.1016/j.tins.2009.01.001

Iadecola, C., and Nedergaard, M. (2007). Glial regulation of the cerebral microvasculature. Nat. Neurosci. 10, 1369-1376. doi: 10.1038/nn2003

Jia, C., Doherty, J. P., Crudgington, S., and Hegg, C. C. (2009). Activation of purinergic receptors induces proliferation and neuronal differentiation in Swiss Webster mouse olfactory epithelium. Neuroscience 163, 120-128. doi: 10.1016/j.neuroscience.2009.06.040

Jia, C., Hayoz, S., Hutch, C. R., Iqbal, T. R., Pooley, A. E., and Hegg, C. C. (2013). An IP3R3- and NPY-expressing microvillous cell mediates tissue homeostasis and regeneration in the mouse olfactory epithelium. PLoS One 8:e58668. doi: 10.1371/journal.pone.0058668

Jia, C., and Hegg, C. C. (2010). NPY mediates ATP-induced neuroproliferation in adult mouse olfactory epithelium. Neurobiol. Dis. 38, 405-413. doi: 10.1016/j. nbd.2010.02.013

Jia, C., and Hegg, C. C. (2012). Neuropeptide Y and extracellular signalregulated kinase mediate injury-induced neuroregeneration in mouse olfactory epithelium. Mol. Cell. Neurosci. 49, 158-170. doi: 10.1016/j.mcn.2011.11.004

Jia, C., and Hegg, C. C. (2015). Effect of IP3R3 and NPY on age-related declines in olfactory stem cell proliferation. Neurobiol. Aging 36, 1045-1056. doi: 10.1016/j. neurobiolaging.2014.11.007

Johansson, B., and Fredholm, B. B. (1995). Further characterization of the binding of the adenosine receptor agonist $\left[{ }^{3 \mathrm{H}}\right.$ ]CGS 21680 to rat brain using autoradiography. Neuropharmacology 34, 393-403. doi: 10.1016/00283908(95)00009-u

Johansson, B., Georgiev, V., and Fredholm, B. B. (1997). Distribution and postnatal ontogeny of adenosine $A_{2 A}$ receptors in rat brain: comparison with dopamine receptors. Neuroscience 80, 1187-1207. doi: 10.1016/s0306-4522(97) 00143-7

Kaelin-Lang, A., Lauterburg, T., and Burgunder, J. M. (1999). Expression of adenosine A2a receptors gene in the olfactory bulb and spinal cord of rat and mouse. Neurosci. Lett. 261, 189-191. doi: 10.1016/s0304-3940(99)00022-1

Kaneda, M., Ito, K., Shigematsu, Y., and Shimoda, Y. (2010). The OFF-pathway dominance of P2X(2)-purinoceptors is formed without visual experience. Neurosci. Res. 66, 86-91. doi: 10.1016/j.neures.2009.09.1714

Kanekar, S., Jia, C., and Hegg, C. C. (2009). Purinergic receptor activation evokes neurotrophic factor neuropeptide $\mathrm{Y}$ release from neonatal mouse olfactory epithelial slices. J. Neurosci. Res. 87, 1424-1434. doi: 10.1002/jnr.21954

Kanjhan, R., Housley, G. D., Burton, L. D., Christie, D. L., Kippenberger, A., Thorne, P. R., et al. (1999). Distribution of the P2X(2) receptor subunit of the ATP-gated ion channels in the rat central nervous system. J. Comp. Neurol. 407, 11-32. doi: 10.1002/(sici)1096-9861(19990428)407:1<11::aid-cne2>3.0.co;2-r

Kidd, E. J., Grahames, C. B., Simon, J., Michel, A. D., Barnard, E. A., and Humphrey, P. P. (1995). Localization of P2X purinoceptor transcripts in the rat nervous system. Mol. Pharmacol. 48, 569-573.

Kim, C. S., and Johnston, D. (2015). A1 adenosine receptor-mediated GIRK channels contribute to the resting conductance of CA1 neurons in the dorsal hippocampus. J. Neurophysiol. 113, 2511-2523. doi: 10.1152/jn.00951.2014

Köles, L., Kató, E., Hanuska, A., Zádori, Z. S., Al-Khrasani, M., Zelles, T., et al. (2016). Modulation of excitatory neurotransmission by neuronal/glial signalling molecules: interplay between purinergic and glutamatergic systems. Purinergic Signal. 12, 1-24. doi: 10.1007/s11302-015-9480-5

Köles, L., Leichsenring, A., Rubini, P., and Illes, P. (2011). P2 receptor signaling in neurons and glial cells of the central nervous system. Adv. Pharmacol. 61, 441-493. doi: 10.1016/b978-0-12-385526-8.00014-x

Kulesskaya, N., Võikar, V., Peltola, M., Yegutkin, G. G., Salmi, M., Jalkanen, S., et al. (2013). CD73 is a major regulator of adenosinergic signalling in mouse brain. PLoS One 8:e66896. doi: 10.1371/journal.pone.0066896

Kuroda, Y. (1978). Physiological roles of adenosine derivatives which are released during neurotransmission in mammalian brain. J. Physiol. 74, 463-470.

Langer, D., Hammer, K., Koszalka, P., Schrader, J., Robson, S., and Zimmermann, H. (2008). Distribution of ectonucleotidases in the rodent brain revisited. Cell Tissue Res. 334, 199-217. doi: 10.1007/s00441-008-0681-x 
Lê, K. T., Villeneuve, P., Ramjaun, A. R., McPherson, P. S., Beaudet, A., and Seguela, P. (1998). Sensory presynaptic and widespread somatodendritic immunolocalization of central ionotropic P2X ATP receptors. Neuroscience 83, 177-190. doi: 10.1016/s0306-4522(97)00365-5

Lohr, C., and Deitmer, J. W. (2010). $\mathrm{Ca}^{2+}$ imaging of glia. Calcium Meas. Methods 43, 221-249. doi: 10.1007/978-1-60761-476-0_12

Lohr, C., Grosche, A., Reichenbach, A., and Hirnet, D. (2014). Purinergic neuron-glia interactions in sensory systems. Pflugers Arch. 466, 1859-1872. doi: 10.1007/s00424-014-1510-6

Lohr, C., Thyssen, A., and Hirnet, D. (2011). Extrasynaptic neuron-glia communication: the how and why. Commun. Integr. Biol. 4, 109-111. doi: $10.4161 /$ cib.4.1.14184

Lucero, M. T. (2013). Peripheral modulation of smell: fact or fiction? Semin. Cell Dev. Biol. 24, 58-70. doi: 10.1016/j.semcdb.2012.09.001

Luskin, M. B., and Price, J. L. (1983a). The laminar distribution of intracortical fibers originating in the olfactory cortex of the rat. J. Comp. Neurol. 216, 292-302. doi: $10.1002 /$ cne. 902160306

Luskin, M. B., and Price, J. L. (1983b). The topographic organization of associational fibers of the olfactory system in the rat, including centrifugal fibers to the olfactory bulb. J. Comp. Neurol. 216, 264-291. doi: 10.1002/cne. 902160305

Luthin, D. R., Lee, K. S., Okonkwo, D., Zhang, P., and Linden, J. (1995). Photoaffinity labeling with $2-\left[2-\left(4\right.\right.$-azido- $3-\left[{ }^{125} \mathrm{I}\right]$-iodophenyl $)$ ethylamino]adenosine and autoradiography with $2-\left[2-\left(4\right.\right.$-amino- $3-\left[{ }^{125} \mathrm{I}\right]$ iodophenyl)ethylamino]adenosine of $\mathrm{A}_{2 \mathrm{~A}}$ adenosine receptors in rat brain. J. Neurochem. 65, 2072-2079. doi: 10.1046/j.1471-4159.1995.65052072.x

Mahan, L. C., McVittie, L. D., Smykrandall, E. M., Nakata, H., Monsma, F. J., Gerfen, C. R., et al. (1991). Cloning and expression of an A1 adenosine receptor from rat-brain. Mol. Pharmacol. 40, 1-7.

Montani, G., Tonelli, S., Elsaesser, R., Paysan, J., and Tirindelli, R. (2006). Neuropeptide $\mathrm{Y}$ in the olfactory microvillar cells. Eur. J. Neurosci. 24, 20-24. doi: $10.1111 / j .1460-9568.2006 .04878 . x$

Nevill, K. R., and Haberly, L. B. (2004). "Olfactory cortex," in The Synaptic Organization of the Brain, 5th Edn. G. M. Shepherd (New York, NY: Oxford University Press), 415-454.

North, R. A. (2016). P2X receptors. Philos. Trans. R. Soc. Lond. B Biol. Sci. 371:20150427. doi: 10.1098/rstb.2015.0427

North, R. A., and Verkhratsky, A. (2006). Purinergic transmission in the central nervous system. Pflugers Arch. 452, 479-485. doi: 10.1007/s00424-006-0060-y

Okada, Y., and Kuroda, Y. (1980). Inhibitory action of adenosine and adenosine analogs on neurotransmission in the olfactory cortex slice of guinea pig - structure-activity relationships. Eur. J. Pharmacol. 61, 137-146. doi: 10.1016/0014-2999(80)90156-9

Otsu, Y., Couchman, K., Lyons, D. G., Collot, M., Agarwal, A., Mallet, J. M., et al. (2015). Calcium dynamics in astrocyte processes during neurovascular coupling. Nat. Neurosci. 18, 210-218. doi: 10.1038/nn.3906

Pani, A. K., Jiao, Y., Sample, K. J., and Smeyne, R. J. (2014). Neurochemical measurement of adenosine in discrete brain regions of five strains of inbred mice. PLoS One 9:e92422. doi: 10.1371/journal.pone.0092422

Pankratov, Y., and Lalo, U. (2015). Role for astroglial $\alpha 1$-adrenoreceptors in gliotransmission and control of synaptic plasticity in the neocortex. Front. Cell. Neurosci. 9:230. doi: 10.3389/fncel.2015.00230

Pankratov, Y., Lalo, U., Verkhratsky, A., and North, R. A. (2007). Quantal release of ATP in mouse cortex. J. Gen. Physiol. 129, 257-265. doi: 10.1085/jgp. 200609693

Pastor-Anglada, M., and Pérez-Torras, S. (2018). Who is who in adenosine transport. Front. Pharmacol. 9:627. doi: 10.3389/fphar.2018.00627

Pelligrino, D. A., Vetri, F., and Xu, H. L. (2011). Purinergic mechanisms in gliovascular coupling. Semin. Cell Dev. Biol. 22, 229-236. doi: 10.1016/j. semcdb.2011.02.010

Pelosi, P., Mastrogiacomo, R., Iovinella, I., Tuccori, E., and Persaud, K. C. (2014). Structure and biotechnological applications of odorant-binding proteins. Appl. Microbiol. Biotechnol. 98, 61-70. doi: 10.1007/s00253-0135383-y

Perrier, S. P., Gleizes, M., Fonta, C., and Nowak, L. G. (2019). Effect of adenosine on short-term synaptic plasticity in mouse piriform cortex in vitro: adenosine acts as a high-pass filter. Physiol. Rep. 7:e13992. doi: 10.14814/phy2. 13992
Petzold, G. C., Albeanu, D. F., Sato, T. F., and Murthy, V. N. (2008). Coupling of neural activity to blood flow in olfactory glomeruli is mediated by astrocytic pathways. Neuron 58, 897-910. doi: 10.1016/j.neuron.2008.04.029

Rezvani, M. E., Mirnajafi-Zadeh, J., Fathollahi, Y., and Palizvan, M. R. (2007). Changes in neuromodulatory effect of adenosine $\mathrm{A} 1$ receptors on piriform cortex field potentials in amygdala kindled rats. Eur. J. Pharmacol. 565, 60-67. doi: 10.1016/j.ejphar.2007.02.010

Rieger, A., Deitmer, J. W., and Lohr, C. (2007). Axon-glia communication evokes calcium signaling in olfactory ensheathing cells of the developing olfactory bulb. Glia 55, 352-359. doi: 10.1002/glia.20460

Rosin, D. L., Hettinger, B. D., Lee, A., and Linden, J. (2003). Anatomy of adenosine $A_{2 A}$ receptors in brain: morphological substrates for integration of striatal function. Neurology 61, S12-S18. doi: 10.1212/01.wnl.0000095205. 33940.99

Rosin, D. L., Robeva, A., Woodard, R. L., Guyenet, P. G., and Linden, J. (1998). Immunohistochemical localization of adenosine $\mathrm{A}_{2 \mathrm{~A}}$ receptors in the rat central nervous system. J. Comp. Neurol. 401, 163-186. doi: 10.1016/b978-012-803724-9.00005-3

Rotermund, N., Winandy, S., Fischer, T., Schulz, K., Fregin, T., Alstedt, N., et al. (2018). Adenosine Al receptor activates background potassium channels and modulates information processing in olfactory bulb mitral cells. J. Physiol. 596, 717-733. doi: 10.1113/jp275503

Roux, L., Madar, A., Lacroix, M. M., Yi, C., Benchenane, K., and Giaume, C. (2015). Astroglial connexin 43 hemichannels modulate olfactory bulb slow oscillations. J. Neurosci. 35, 15339-15352. doi: 10.1523/JNEUROSCI.0861-15.2015

Rungta, R. L., Chaigneau, E., Osmanski, B. F., and Charpak, S. (2018). Vascular compartmentalization of functional hyperemia from the synapse to the pia. Neuron 99, 362.e4-375.e4. doi: 10.1016/j.neuron.2018.06.012

Schmid, R., and Evans, R. J. (2019). ATP-gated P2X receptor channels: molecular insights into functional roles. Annu. Rev. Physiol. 81, 43-62. doi: 10.1146/annurev-physiol-020518-114259

Schoen, S. W., and Kreutzberg, G. W. (1995). Evidence that 5'-Nucleotidase is associated with malleable synapses-an enzyme cytochemical investigation of the olfactory bulb of adult rats. Neuroscience 65, 37-50. doi: 10.1016/03064522(94)00469-1

Schoen, S. W., and Kreutzberg, G. W. (1997). 5'-nucleotidase enzyme cytochemistry as a tool for revealing activated glial cells and malleable synapses in CNS development and regeneration. Brain Res. Protoc. 1, 33-43. doi: 10.1016/s1385-299x(96)00006-2

Scholfield, C. N. (1978). Depression of evoked potentials in brain slices by adenosine compounds. Br. J. Pharmacol. 63, 239-244. doi: 10.1111/j.1476-5381. 1978.tb09752.x

Schulz, K. (2018). ATP und Adenosin als Modulatoren Neuronaler Kommunikation im Bulbus Olfactorius der Maus. Ph. D. thesis. Hamburg: University of Hamburg.

Schulz, K., Rotermund, N., Grzelka, K., Benz, J., Lohr, C., and Hirnet, D. (2018). Adenosine Al receptor-mediated attenuation of reciprocal dendrodendritic inhibition in the mouse olfactory bulb. Front. Cell. Neurosci. 11:435. doi: $10.3389 /$ fncel.2017.00435

Sebastião, A. M., and Ribeiro, J. A. (2009). Tuning and fine-tuning of synapses with adenosine. Curr. Neuropharmacol. 7, 180-194. doi: 10.2174/ 157015909789152128

Sebastião, A. M., and Ribeiro, J. A. (2015). Neuromodulation and metamodulation by adenosine: impact and subtleties upon synaptic plasticity regulation. Brain Res. 1621, 102-113. doi: 10.1016/j.brainres.2014.11.008

Shigetomi, E., Patel, S., and Khakh, B. S. (2016). Probing the complexities of astrocyte calcium signaling. Trends Cell Biol. 26, 300-312. doi: 10.1016/j.tcb. 2016.01.003

Sickmann, T., and Alzheimer, C. (2003). Short-term desensitization of G-proteinactivated, inwardly rectifying $\mathrm{K}^{+}$(GIRK) currents in pyramidal neurons of rat neocortex. J. Neurophysiol. 90, 2494-2503. doi: 10.1152/jn.00112.2003

Simon, J., Webb, T. E., and Barnard, E. A. (1997). Distribution of S-35 dATP $\alpha$ S binding sites in the adult rat neuraxis. Neuropharmacology 36, 1243-1251. doi: 10.1016/s0028-3908(97)00124-x

Singaravelu, K., Lohr, C., and Deitmer, J. W. (2006). Regulation of store-operated calcium entry by calcium-independent phospholipase $A_{2}$ in rat cerebellar astrocytes. J. Neurosci. 26, 9579-9592. doi: 10.1523/JNEUROSCI.260406.2006 
Snyder, S. H. (1985). Adenosine as a neuromodulator. Annu. Rev. Neurosci. 8, 103-124. doi: 10.1146/annurev.ne.08.030185.000535

Sperlágh, B., Heinrich, A., and Csölle, C. (2007). P2 receptor-mediated modulation of neurotransmitter release-an update. Purinergic Signal. 3, 269-284. doi: 10.1007/s11302-007-9080-0

Stavermann, M., Buddrus, K., St John, J. A., Ekberg, J. A. K., Nilius, B., Deitmer, J. W., et al. (2012). Temperature-dependent calcium-induced calcium release via $\mathrm{InsP}_{3}$ receptors in mouse olfactory ensheathing glial cells. Cell Calcium 52, 113-123. doi: 10.1016/j.ceca.2012.04.017

Stavermann, M., Meuth, P., Doengi, M., Thyssen, A., Deitmer, J. W., and Lohr, C. (2015). Calcium-induced calcium release and gap junctions mediate large-scale calcium waves in olfactory ensheathing cells in situ. Cell Calcium 58, 215-225. doi: 10.1016/j.ceca.2015.05.003

Sun, W., McConnell, E., Pare, J.-F., Xu, Q., Chen, M., Peng, W., et al. (2013). Glutamate-dependent neuroglial calcium signaling differs between young and adult brain. Science 339, 197-200. doi: 10.1126/science. 1226740

Taruno, A. (2018). ATP release channels. Int. J. Mol. Sci. 19:E808. doi: 10.3390/ijms 19030808

Thyssen, A., Hirnet, D., Wolburg, H., Schmalzing, G., Deitmer, J. W., and Lohr, C. (2010). Ectopic vesicular neurotransmitter release along sensory axons mediates neurovascular coupling via glial calcium signaling. Proc. Natl. Acad. Sci. U S A 107, 15258-15263. doi: 10.1073/pnas.1003501107

Thyssen, A., Stavermann, M., Buddrus, K., Doengi, M., Ekberg, J. A., St John, J. A., et al. (2013). Spatial and developmental heterogeneity of calcium signaling in olfactory ensheathing cells. Glia 61, 327-337. doi: 10.1002/glia. 22434

Trieu, B. H., Kramár, E. A., Cox, C. D., Jia, Y., Wang, W., Gall, C. M., et al. (2015). Pronounced differences in signal processing and synaptic plasticity between piriform-hippocampal network stages: a prominent role for adenosine. J. Physiol. 593, 2889-2907. doi: 10.1113/jp270398

Valverde, F., and Lopez-Mascaraque, L. (1991). Neuronal arrangements in the olfactory glomeruli of the hedgehog. J. Comp. Neurol. 307, 658-674. doi: 10.1002/cne.903070411

Verkhratsky, A., Krishtal, O. A., and Burnstock, G. (2009). Purinoceptors on Neuroglia. Mol. Neurobiol. 39, 190-208. doi: 10.1007/s12035-009-8063-2

Verkhratsky, A., Rodríguez, J. J., and Parpura, V. (2012). Calcium signalling in astroglia. Mol. Cell. Endocrinol. 353, 45-56. doi: 10.1016/j.mce.2011. 08.039

Vogalis, F., Hegg, C. C., and Lucero, M. T. (2005a). Electrical coupling in sustentacular cells of the mouse olfactory epithelium. J. Neurophysiol. 94, 1001-1012. doi: 10.1152/jn.01299.2004
Vogalis, F., Hegg, C. C., and Lucero, M. T. (2005b). Ionic conductances in sustentacular cells of the mouse olfactory epithelium. J. Physiol. 562, 785-799. doi: 10.1113/jphysiol.2004.079228

Vulchanova, L., Arvidsson, U., Riedl, M., Wang, J., Buell, G., Surprenant, A., et al. (1996). Differential distribution of two ATP-gated ion channels (P-2X receptors) determined by immunocytochemistry. Proc. Natl. Acad. Sci. U S A 93, 8063-8067. doi: 10.1073/pnas.93. 15.8063

Webb, T. E., Henderson, D., King, B. F., Wang, S., Simon, J., Bateson, A. N., et al. (1996). A novel G protein-coupled P2 purinoceptor (P2Y3) activated preferentially by nucleoside diphosphates. Mol. Pharmacol. 50, 258-265.

Wilson, D. A., Xu, W., Sadrian, B., Courtiol, E., Cohen, Y., and Barnes, D. C. (2014). Cortical odor processing in health and disease. Prog. Brain Res. 208, 275-305. doi: 10.1016/b978-0-444-63350-7.00011-5

Yang, S. C., Chiu, T. H., Yang, H. W., and Min, M. Y. (2007). Presynaptic adenosine A1 receptors modulate excitatory synaptic transmission in the posterior piriform cortex in rats. Brain Res. 1156, 67-79. doi: 10.1016/j.brainres. 2007.04.049

Yi, C., Ezan, P., Fernández, P., Schmitt, J., Sáez, J. C., Giaume, C., et al. (2017). Inhibition of glial hemichannels by boldine treatment reduces neuronal suffering in a murine model of Alzheimer's disease. Glia 65, 1607-1625. doi: $10.1002 /$ glia.23182

Zimmermann, H. (2006). Nucleotide signaling in nervous system development. Pflugers Arch. 452, 573-588. doi: 10.1007/s00424-006-0067-4

Zimmermann, H. (2011). Purinergic signaling in neural development. Semin. Cell Dev. Biol. 22, 194-204. doi: 10.1016/j.semcdb.2011.02.007

Zimmermann, H., Zebisch, M., and Sträter, N. (2012). Cellular function and molecular structure of ecto-nucleotidases. Purinergic Signal. 8, 437-502. doi: 10.1007/s11302-012-9309-4

Conflict of Interest Statement: The authors declare that the research was conducted in the absence of any commercial or financial relationships that could be construed as a potential conflict of interest.

Copyright (C) 2019 Rotermund, Schulz, Hirnet and Lohr. This is an open-access article distributed under the terms of the Creative Commons Attribution License (CC BY). The use, distribution or reproduction in other forums is permitted, provided the original author(s) and the copyright owner(s) are credited and that the original publication in this journal is cited, in accordance with accepted academic practice. No use, distribution or reproduction is permitted which does not comply with these terms. 